Article

\title{
Unraveling Microbial Volatile Elicitors Using a Transparent Methodology for Induction of Systemic Resistance and Regulation of Antioxidant Genes at Expression Levels in Chili against Bacterial Wilt Disease
}

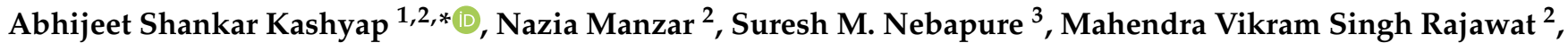 \\ Man Mohan Deo ${ }^{4}$, Jyoti Prakash Singh ${ }^{2,5}$, Amit Kumar Kesharwani ${ }^{1}$, Ravinder Pal Singh ${ }^{1}$, S. C. Dubey ${ }^{6,7}$ \\ and Dinesh Singh 1 ,*
}

check for updates

Citation: Kashyap, A.S.; Manzar, N.; Nebapure, S.M.; Rajawat, M.V.S.; Deo, M.M.; Singh, J.P.; Kesharwani, A.K.; Singh, R.P.; Dubey, S.C.; Singh, D.

Unraveling Microbial Volatile

Elicitors Using a Transparent Methodology for Induction of Systemic Resistance and Regulation of Antioxidant Genes at Expression Levels in Chili against Bacterial Wilt Disease. Antioxidants 2022, 11, 404. https://doi.org/10.3390/ antiox11020404

Academic Editor: Vittoria Locato

Received: 12 January 2022

Accepted: 9 February 2022

Published: 16 February 2022

Publisher's Note: MDPI stays neutral with regard to jurisdictional claims in published maps and institutional affiliations.

Copyright: (c) 2022 by the authors. Licensee MDPI, Basel, Switzerland. This article is an open access article distributed under the terms and conditions of the Creative Commons Attribution (CC BY) license (https:// creativecommons.org/licenses/by/ $4.0 /)$.
1 Division of Plant Pathology, ICAR-Indian Agricultural Research Institute, New Delhi 110012, India; amitmicro1@gmail.com (A.K.K.); ravinder.20033@gmail.com (R.P.S.)

2 Plant Pathology Laboratory, ICAR-National Bureau of Agriculturally Important Microorganisms, Maunath Bhanjan 275103, India; naziamanzar786@gmail.com (N.M.); rajawat.mvs@gmail.com (M.V.S.R.); jyotipsingh58@outlook.com (J.P.S.)

3 Division of Entomology, ICAR-IARI, New Delhi 110012, India; nebapure.mahadev@icar.gov.in

4 Farm Machinery and Power, ICAR-Indian Institute of Pulses Research, Kanpur 208024, India; mm.deo@icar.org.in

5 Division of Biochemistry, ICAR-Indian Agricultural Research Institute, New Delhi 110012, India

6 Division of Plant Quarantine, ICAR-NBPGR, New Delhi 110012, India; scdube2002@yahoo.co.in

7 Krishi Bhawan, Indian Council of Agricultural Research, New Delhi 110001, India

* Correspondence: abhijeet4497@gmail.com (A.S.K.); dinesh_iari@rediffmail.com (D.S.)

\begin{abstract}
Microbial volatiles benefit the agricultural ecological system by promoting plant growth and systemic resistance against diseases without harming the environment. To explore the plant growthpromoting efficiency of VOCs produced by Pseudomonas fluorescens PDS1 and Bacillus subtilis KA9 in terms of chili plant growth and its biocontrol efficiency against Ralstonia solanacearum, experiments were conducted both in vitro and in vivo. A closure assembly was designed using a half-inverted plastic bottle to demonstrate plant-microbial interactions via volatile compounds. The most common volatile organic compounds were identified and reported; they promoted plant development and induced systemic resistance (ISR) against wilt pathogen $R$. solanacearum. The PDS1 and KA9 VOCs significantly increased defensive enzyme activity and overexpressed the antioxidant genes PAL, POD, SOD, WRKYa, PAL1, DEF-1, CAT-2, WRKY40, HSFC1, LOX2, and NPR1 related to plant defense. The overall gene expression was greater in root tissue as compared to leaf tissue in chili plant. Our findings shed light on the relationship among rhizobacteria, pathogen, and host plants, resulting in plant growth promotion, disease suppression, systemic resistance-inducing potential, and antioxidant response with related gene expression in the leaf and root tissue of chili.
\end{abstract}

Keywords: B. subtilis KA9; volatile compounds; GC-MS spectroscopy; systemic resistance; P. fluorescens PDS1; real-time PCR; transmission electron microscopy; Ralstonia solanacearum

\section{Introduction}

Bacterial wilt is a catastrophic soil-borne disease that affects nearly 450 crop species, primarily those belonging to the Solanaceae family [1,2]. Bacterial wilt is found all over the world in tropical and subtropical climates [3]. In the management of soil-borne plant diseases, the biological control approach is an environmentally benign, cost-effective, and simple-to-implement strategy. Plant growth-promoting bacteria are considered the greatest biocontrol agents, with the ability to inhibit the population of pathogenic microbes and induce systemic resistance in plants against disease [4]. Antimicrobial compound production, nitrogen fixation, phytohormone production, and mineral solubilization are some 
of the mechanisms involved in plant growth promotion [5-7], including volatile organic compounds (VOCs) [8-11]. Plant growth-promoting rhizobacteria (PGPR) produce volatile organic compounds (VOCs), which are gaseous metabolic chemicals exhaled from bacterial cells that are active even at a low concentration under normal conditions [12]. The VOCs produced by PGPRs are beneficial in suppressing plant infections, increasing plant development, and establishing systemic resistance [10,13-16]. VOCs offer an advantage over other biocontrol and growth-regulating mechanisms in that they do not necessitate physical contact with pathogens or plant components, whereas most other methods for suppressing phytopathogens and boosting plant development must [4,5]. Bacterial VOCs can have direct antibacterial action. Many plant pathogen biocontrol agents, such as Pseudomonas and Bacillus, have been identified to release VOCs exhibiting antibacterial action [5,8-12,17]. For example, VOCs generated by Bacillus spp., such as benzaldehyde, 1,2-benzisothiazol$3(2 H)$-one, and 1,3-butadiene, were found to have a substantial inhibitory effect against $R$. solanacearum, which causes bacterial wilt disease [10]. It was reported in many studies that genera Bacillus, Pseudomonas, Serratia, and Arthrobacter are linked to plant growth promotion and the induction of systemic resistance $[13,14,18,19]$. The plant growth-promoting VOCs 2,3-butanediol and acetoin were found to be produced by Bacillus subtilis GB03 and B. amyloliquefaciens IN937 [10]. In addition to boosting growth, VOCs induce systemic resistance in plants, resulting in tolerance to both biotic and abiotic factors. A Bacillus VOC 2,3-butanediol was demonstrated to greatly improve resistance in Arabidopsis against Erwinia carotovora subsp. carotovora [20]. 3-Pentanol and 2-butanone were also reported to be effective against the pathogen Pseudomonas syringae pv. lachrymans, which causes cucumber bacterial angular leaf spot [21]. The effects of bacterial VOCs on plant development and systemic resistance have been studied in the literature. Bacterial VOCs were shown in some experiments to interact with plant hormones by interfering with morphogenetic processes, causing the plant to develop more quickly $[10,13,22,23]$. After being exposed to Bacillus subtilis GBO3 VOCs, a transcriptional study of Arabidopsis revealed that the VOCs can regulate auxin and result in the commencement of growth promotion [22]. Furthermore, VOCs influenced the transcriptional expression of genes related to the ethylene response factor and ethylene production, such as WRKY, implying that VOCs can promote plant disease resistance in poplar [24]. Bacillus species are the most effective PGPR bacteria because they can produce spores that survive in harsh environments [25]. The major goal of this study was to investigate the impact of VOCs produced by Bacillus strain KA9 and Pseudomonas strain PDS-1 on plant growth promotion, induction of systemic resistance, and gene transcriptional expression in chili.

\section{Materials and Methods}

\subsection{Plant Growth-Promoting Rhizobacteria Strains}

Rhizobacteria and R. solanacearum cultures used in this study were taken from the Plant Bacteriology Lab, Division of Plant Pathology, Indian Council of Agricultural ResearchIndian Agricultural Research Institute, New Delhi, with accession numbers MT491101 and MN368159. The rhizobacteria cultures utilized in this investigation were collected from diverse agroclimatic zones, characterized in 2019, and kept in the lab in glycerol stock, slants, and active plates. These studies were run since 2019 and repeated three times to ensure a valid and stable hypothesis. These cultures were grown in TSA medium (tryptone $17.0 \mathrm{~g} / \mathrm{L}$, soya peptone $3.0 \mathrm{~g} / \mathrm{L}$, sodium chloride $5.0 \mathrm{~g} / \mathrm{L}$, dextrose $2.5 \mathrm{~g} / \mathrm{L}$, dipotassium hydrogen phosphate $2.5 \mathrm{~g} / \mathrm{L}$, and agar $15.0 \mathrm{~g} / \mathrm{L}$ ), $\mathrm{KB}$ medium (proteose peptone $20.0 \mathrm{~g} / \mathrm{L}$, dipotassium hydrogen phosphate $1.50 \mathrm{~g} / \mathrm{L}$, magnesium sulfate heptahydrate $1.50 \mathrm{~g} / \mathrm{L}$, and agar $20.0 \mathrm{~g} / \mathrm{L}$ ), CPG medium (casamino acid $1 \mathrm{~g} / \mathrm{L}$, peptone $10 \mathrm{~g} / \mathrm{L}$, glucose $5 \mathrm{~g} / \mathrm{L}$, and agar $17 \mathrm{~g} / \mathrm{L}$, supplemented with 2,3,5-triphenyl tetrazolium chloride at $0.005 \%$ ) [26]. A single isolated colony of bacterium (irregular, gray-white, round, opaque, thick ridges, smooth, moist, medium-sized colony) was used for growth on a YGCA (yeast glucose calcium carbonate agar) slant. All cultures were maintained on the YGCA slant and stored at $4{ }^{\circ} \mathrm{C}$ for further use. 
2.2. Detection of Volatile Inhibitory Compounds Produced by Rhizobacteria against R. solanacearum under In Vitro Conditions

A dual-plate assay was first used to determine the potential of rhizobacterial isolates PDS1 and KA9 in producing volatile inhibitory compounds. A colony of each rhizobacterium was smeared on an NA plate, and the same process was repeated for $R$. solanacearum on a separate CPG plate. The agar plate covers were then removed, and the $R$. solanacearuminoculated plate was flipped over the rhizobacteria-inoculated plate (Figure 1), whereby the sealed plates featured antagonists in the lower plate and pathogens in the upper plate. Parafilm was used to seal the Petri plates together before they were placed in an incubator at $25{ }^{\circ} \mathrm{C}$ for 7 days. Control plates were established by inverting $R$. solanacearum-inoculated plates over a plain agar plate (designated as D1 in this experiment). The growth of $R$. solanacearum in control was compared against its growth in the presence of the rhizobacteria (designated as D2).



(a)

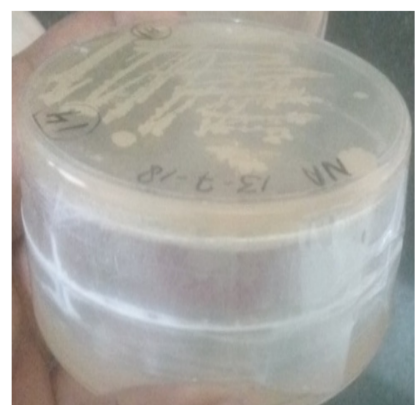

(b)

Figure 1. (a) Double-plate assay for the detection of volatile inhibitory compounds produced by rhizobacteria against $R$. solanacearum under in vitro conditions; (b) lateral view of sealed plates carrying antagonists in the lower plate and pathogens in the upper plate.

The inhibition (\%) by the rhizobacteria was calculated using D1 and D2 (Equation (1)).

$$
\text { Growth inhibition }=\frac{D 1-D 2}{D 1} \times 100,
$$

where $D 1$ is the diameter growth of $R$. solanacearum only (control), and $D 2$ is the diameter growth of $R$. solanacearum co-inoculated with rhizobacteria.

\subsection{Study on Induced Systemic Resistance (ISR) of Rhizobacteria against R. solanacearum in Chili Plants}

\subsubsection{Rhizobacterial Cultures and Chili Seedlings}

Rhizobacterial isolates Pseudomonas fluorescens (PDS1) and Bacillus subtillis (KA9) were cultured on a sterile LB agar plate at $28 \pm 1{ }^{\circ} \mathrm{C}$ for $48 \mathrm{~h}$. They were diluted with sterile distilled water to $10^{8} \mathrm{CFU} / \mathrm{mL}$. The pathogen was grown on CPG agar medium at $28 \pm 1{ }^{\circ} \mathrm{C}$ for $48 \mathrm{~h}$, and the inoculum load was maintained at $10^{8} \mathrm{CFU} / \mathrm{mL}$. Chili cv. Pusa Jwala seeds were planted in seed starter trays with 96 wells containing a 2:1:1 mixture of peat mass, vermiculite, and sand in a Phytotron under controlled conditions at $28 \pm 2{ }^{\circ} \mathrm{C}$, watered daily. As illustrated in Figure 2, the lower part of the closer assembly contained broth for the optimum growth of biocontrol agents producing the volatile compounds transmitted to the upper part of bottle, which interfered with the pathogen $R$. solanacearum present in the rhizospheric zone of the upper part of the assembly where the chili was transplanted. The plants were simultaneously treated with rhizobacteria and $R$. solanacearum UTT-25 5 days after transplantation. After $48 \mathrm{~h}$, cultures of wilt pathogen and biocontrol agents were scraped from the Petri plates and mixed in sterile distilled water to maintain the bacterial population at $0.1 \mathrm{OD}(600 \mathrm{~nm})$ according to a spectrophotometer. Then, a $2 \mathrm{~mL}$ suspension of $R$. solanacearum was inoculated in the rhizospheric zone after 5 days of transplanting. Subsequently, $5 \mathrm{~mL}$ of antagonists were inoculated in the lower chamber of the assembly. 
The plants treated with pathogen $R$. solanacearum only and uninoculated plants were also maintained as positive and negative controls, respectively. The observations were recorded at 7 day intervals for 40 days after transplanting. Three replicates were maintained for the experiment.



(a)

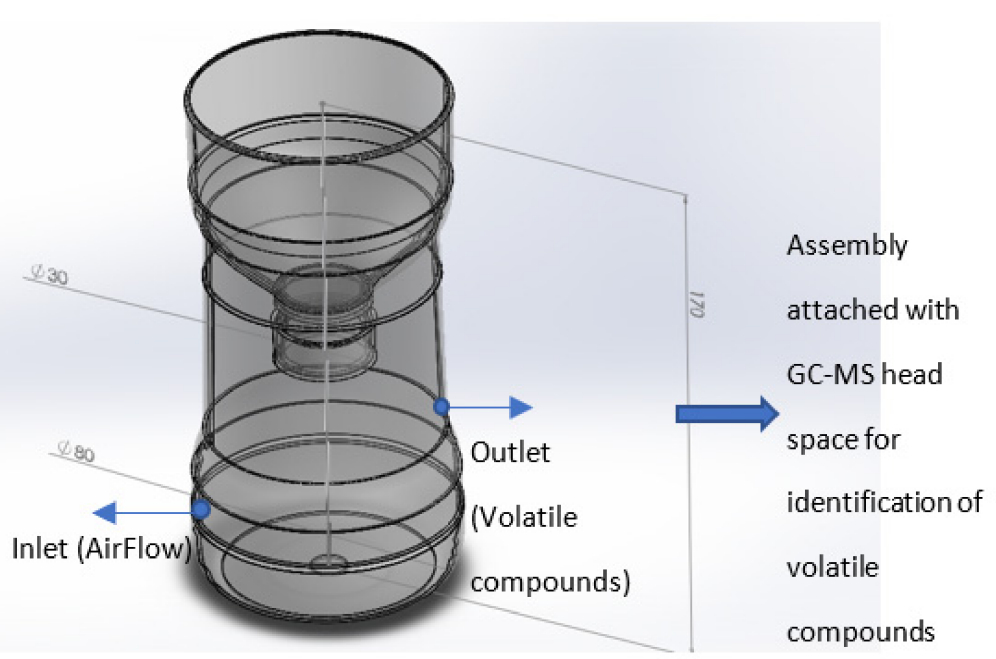

(b)

Figure 2. (a,b) A low-cost closed assembly resembling a transparent pot system using a half-inverted plastic bottle to demonstrate plant-microbial interactions via volatile compounds.

The seven treatments were as follows: T-1 (control), T-2 (B. subtilis KA9), T-3 (P. fluorescens PDS1), T-4 (B. subtilis KA9 + R. solanacearum UTT-25), T-5 (P. fluorescens PDS1 + R. solanacearum UTT-25), T6 (P. fluorescens PDS1 + B. subtilis KA9 + R. solanacearum UTT-25), and T-7 (R. solanacearum UTT-25). The surviving plants were assessed for wilt intensity and fresh and dry weight at the time of harvesting. The degree of wilt was studied at 7 day intervals for 60 days. The average percentage of wilt in each treatment was calculated by following the scale of disease severity, where 1 indicates no symptoms, 2 indicates one wilted leaf, 3 indicates two to three wilted leaves, 4 indicates four or more wilted leaves, and 5 indicates that the entire plant has wilted (dead plant). Wilt incidence was estimated using the 30 days after inoculation according to the following formula [26]:

$$
\text { Wilt intensity }(\%)(\mathrm{I})=\left[\sum\left(\mathrm{n}_{\mathrm{i}} \times \mathrm{v}_{\mathrm{i}}\right) \div(\mathrm{V} \times \mathrm{N})\right] 100 \text {, }
$$


where $n_{i}$ is the number of plants with a specific disease rating, $v_{i}$ is the disease rating $(1,2,3$, 4 , or 5), $\mathrm{V}$ is the highest disease rating, and $\mathrm{N}$ is the number of plants observed. Biocontrol efficacy was calculated as described in [27]. Growth-promoting efficacy was calculated as a function of the dry weight of the root and shoot of the plant, as described in [28].

\subsubsection{Preparation for Enzyme Extraction}

Approximately $0.5 \mathrm{~g}$ of leaf tissue was collected from chili cv. Pusa Jwala for enzyme extraction under each treatment at timepoints of $0,24,48,72$, and $96 \mathrm{~h}$. Leaf tissue and root tissue were homogenized in $0.1 \mathrm{M}$ sodium phosphate buffer $(20 \mathrm{~mL}), \beta$-mercaptoethanol $(0.2 \mathrm{~mL})$, and $1.0 \mathrm{~g}$ of insoluble polyvinyl pyrrolidone (PVPP), centrifuged at 12,000 rpm for $30 \mathrm{~min}$ at $4{ }^{\circ} \mathrm{C}$. In the supernatant, the concentration of ammonium sulfate was measured. Extraction buffer $(3 \mathrm{~mL})$ was used to recover the pellets from the supernatant after $1 \mathrm{~h}$ of centrifugation at $12,000 \mathrm{rpm}$ for $30 \mathrm{~min}$ at $40^{\circ} \mathrm{C}$, and the pellets were utilized for assays to evaluate defense enzymes such as SOD, POD, PPO, and PAL.

\subsubsection{Estimation of PPO Activity}

The polyphenol oxidase activity was determined according to the method described in [29]. The reaction mixture contained potassium phosphate buffer ( $2 \mathrm{~mL})$, pyrogallol $(1 \mathrm{~mL})$, and $0.1 \mathrm{~mL}$ of the enzyme extract, kept at room temperature for $3 \mathrm{~min}$ for incubation. The reaction was terminated by adding $0.5 \mathrm{~mL}$ of sulfuric acid, and the OD at $480 \mathrm{~nm}$ was measured immediately using a UV/Vis spectrophotometer (Hitachi, U-2900) against the control of potassium phosphate buffer $(2 \mathrm{~mL})$ and pyrogallol $(1 \mathrm{~mL})$. Sulfuric acid $(0.5 \mathrm{~mL})$ was added and incubated for $3 \mathrm{~min}$ at room temperature. The enzyme extract $(0.1 \mathrm{~mL})$ was added after 3 min of incubation, before immediately recording the OD value. The reaction mixture without the enzyme served as the blank.

One unit of enzyme activity was described by a change in absorbance of 0.1 per minute. The specific activity was calculated using the following formula:

$$
(\mathrm{A} \times 3 / 0.1) / 3=\text { specific activity } / \mathrm{min} / \mathrm{mg} \text { protein, }
$$

where $\mathrm{A}$ is the difference in absorbance of the sample and the control (OD S - OD C).

\subsubsection{Estimation of POD Activity}

Peroxidase activity was determined using the method described in [29]. Briefly, $1 \mathrm{~mL}$ of hydrogen peroxide $\left(\mathrm{H}_{2} \mathrm{O}_{2}\right), 2 \mathrm{~mL}$ of potassium phosphate buffer, and $1 \mathrm{~mL}$ of pyrogallol were combined. The enzyme extract $(0.1 \mathrm{~mL})$ was added to the mixture and left to rest for $3 \mathrm{~min}$ at room temperature. Then, $0.5 \mathrm{~mL}$ of sulfuric acid was added to terminate the reaction. The OD at $420 \mathrm{~nm}$ was measured for $5 \mathrm{~min}$, and one unit of enzyme activity was defined as a change in absorbance of 0.1 per minute. The specific activity was calculated using the following formula:

$$
(\mathrm{A} \times 3 / 0.1) / 3=\text { specific activity } / \mathrm{min} / \mathrm{mg} \text { protein, }
$$

where $\mathrm{A}$ is the difference in absorbance of the sample and the control (OD S - OD C).

\subsubsection{Estimation of SOD Activity}

Superoxide dismutase activity was determined using the NBT method described by Beauchamp and Fridovich [30]. First, 0.1 M phosphate buffer (pH 7.8), $13 \mathrm{mM}$ methionine, $0.1 \mathrm{mM}$ EDTA, $75 \mathrm{M}$ NBT, $0.1 \mathrm{~mL}$ of enzyme extract, and $2 \mathrm{M}$ riboflavin were combined in a $3.0 \mathrm{~mL}$ reaction mixture. The test tubes containing the reaction mixture were placed in an incubator for $10 \mathrm{~min}$ and shaken in the light. The reaction was halted by turning off the light and covering the tubes with a black cloth. The OD at $560 \mathrm{~nm}$ was used to quantify SOD activity. A 50\% reduction in NBT was denoted as one unit of enzyme activity according to 
the OD value of the reaction solution. The specific activity of SOD was calculated using the following formula:

$$
(100-(\text { OD S/OD LC) } 100) / 50=x,
$$

where $x$ is the specific activity per mg protein in the enzyme extract. One unit of enzyme activity was defined as a $50 \%$ reduction in the blue color formed by NBT/30 min/mg protein. OD S $=$ OD T - OD C, where OD T is the absorbance of the sample, OD C is the absorbance of the dark control, and OD LS is the absorbance of the light control.

\subsubsection{Estimation of PAL Activity}

Chili leaves and roots ( $0.2 \mathrm{~g}$ each) of cv. Pusa Jwala were homogenized in $2 \mathrm{~mL}$ of $25 \mathrm{mM}$ borate buffer (100 mM borate and $150 \mathrm{mM} \mathrm{NaCl}, \mathrm{pH} 8.8$ ) containing $2 \mu \mathrm{L}$ of $\beta$-mercaptoethanol and a trace amount of polyvinyl polypyrrolidone (PVP). The homogenate was filtered through a $0.45 \mu \mathrm{m}$ nylon membrane filter and centrifuged at $12,000 \times \mathrm{g}$ for $10 \mathrm{~min}$, and the supernatant was used for the enzyme activity assay as described by Sadisivam and Manickam [31]. One unit of the enzyme activity was defined as a one unit increase in absorbance per minute. The OD at $290 \mathrm{~nm}$ was measured every 15 min until it became constant. A change in absorbance of 0.1 per hour was denoted as one unit of enzyme activity.

\subsection{Colonization Behavior of Different Groups of Rhizobacteria and R. solanacearum on Chili Root}

After 30 days of inoculation, the levels of $R$. solanacearum and rhizobacteria in the plant system were assessed. Three chili plants were randomly selected from each treatment, and $1 \mathrm{~g}$ of the root was crushed in $5 \mathrm{~mL}$ of a $0.85 \%$ brine solution, before diluting serially. To determine the growth of $R$. solanacearum and rhizobacteria, a $100 \mu \mathrm{L}$ aliquot was disseminated equally over TTC and LA media. The infected Petri plates were incubated at $28^{\circ} \mathrm{C}$ for $48 \mathrm{~h}$. The number of colony-forming units (CFU) per gram of plant fresh weight was counted. The trials were carried out in a glass house in triplicate under identical conditions, and the data were pooled for statistical analysis.

\subsection{ISR Activity of Rhizobacteria VOCs in a Half-Inverted Plastic Bottle Representing an Earth System Assembly}

A low-cost closed assembly resembling an Earth system was established using a halfinverted plastic bottle to demonstrate plant-microbial interactions via volatile compounds. This system collects microbial volatile compounds from the interior of an inverted plastic bottle, featuring a downward-pointing spout covered with a muslin cloth. The closure has an open pore through which volatile compounds may flow from the inverted plastic bottle (Figure 2). The lower part of the assembly contained broth for the optimum growth of biocontrol agents producing the volatile compounds transmitted to the upper part of the assembly, where they interfered with the pathogen $R$. solanacearum present in the rhizospheric zone. The jar assembly was placed at $25^{\circ} \mathrm{C}$ in a $12 \mathrm{~h}$ light $/ 12 \mathrm{~h}$ dark photoperiod for 30 days. The induction of systemic resistance was determined by measuring the difference in regulation of defensive enzymes PAL, PPO, POD, and SOD in the root and shoot tissues of seven different treatments. The seven treatments were as follows: T-1 (uninoculated control treated with sterile water only), T-2 (B. subtilis KA9), T-3 (P. fluorescens PDS1), T-4 (B. subtilis KA9 + R. solanacearum UTT-25), T-5 (P. fluorescens PDS1 + R. solanacearum UTT-25), T6 (P. fluorescens PDS1 + B. subtilis KA9 + R. solanacearum UTT-25), and T-7 (R. solanacearum UTT-25 only).

\subsection{GC/MS Analysis of Volatile Compounds Produced by Rhizobacteria Strains}

The separation and identification of volatile compounds from the plastic bottle assembly were achieved using a Shimadzu QP 2000 fitted with an Rtx-5ms column $(30 \mathrm{~m} \times 0.25 \mathrm{~mm})$ packed with $95 \%$ dimethyl poly siloxane for GC-MS analysis. Helium with a flow rate of $1 \mathrm{~mL} / \mathrm{min}$ was used as the carrier gas. First, $1.0 \mu \mathrm{L}$ of each sample was injected into the injection port with temperature maintained at $230{ }^{\circ} \mathrm{C}$. The initial temperature of the oven 
was programmed at $40^{\circ} \mathrm{C}$ for $4 \mathrm{~min}$, before it was increased to $220^{\circ} \mathrm{C}$ with $5^{\circ} \mathrm{C}$ ramping rate and held for $2 \mathrm{~min}$. Finally, the temperature was increased to $270{ }^{\circ} \mathrm{C}$ with a ramping rate of $15{ }^{\circ} \mathrm{C}$ and held for $1 \mathrm{~min}$. The running time of the sample was $45 \mathrm{~min}$. The ion source was kept at a constant temperature of $200^{\circ} \mathrm{C}$. For GC-MS analysis, electron impact ionization (EII) at $70 \mathrm{eV}$ was utilized, and the data were analyzed using TIC (total ion count) for compound identification and quantification. The spectra of each molecule were compared to a recognized spectral database in the GC-MS library (NIST14), and the data were then processed by measuring the peak regions using Turbo-Mass-OCPTVS-Demo SPL software.

\subsection{Population Counts of R. solanacearum in Pot Experiments with Chili}

The roots of the chili plants cv. Pusa Jwala were collected. Then, $5 \mathrm{~mL}$ of $0.85 \%$ brine solution was used to crush $1.0 \mathrm{~g}$ of root, before diluting serially. To determine rhizobacteria growth, a $100 \mu \mathrm{L}$ aliquot was evenly disseminated on Luria agar medium. The inoculated Petri plates were incubated at $28 \pm 1^{\circ} \mathrm{C}$ for $48 \mathrm{~h}$. The colonies were enumerated to compute the number of colony-forming units (CFU) per gram of plant fresh weight.

\subsection{Expression of Rhizobacteria-Mediated Defense-Related Genes against R. solanacearum in Chili}

\subsubsection{RNA Isolation}

First, $100 \mathrm{mg}$ of fresh root and leaf samples were carefully gathered from the infected spot (about $10 \mathrm{~mm}$ ) and homogenized in liquid nitrogen. With an RNA isolation kit, total RNA was extracted from the tissues using the silica spin column technique to obtain pure and undamaged RNA (Genei, Bangalore, India) (Supplementary Materials).

\subsubsection{Quantification of the Isolated RNA}

Diluting the samples with RNase-free water allowed the RNA content to be quantified. The absorbance of the samples was measured at 260 and $280 \mathrm{~nm}$, where $40 \mathrm{~g} / \mathrm{mL}$ RNA equates to an absorbance reading of 1.0 at $260 \mathrm{~nm}$. The A260/A280 ratio was used to determine the sample purity. The RNA purity is judged satisfactory for values $>1.6$.

\subsubsection{Electrophoretic Separation of RNA}

The following reagents /buffers were used: $0.8 \%$ agarose, $1 \mathrm{mM}$ EDTA, $40 \mathrm{mM}$ Tris acetate, $0.25 \%$ bromophenol blue, $0.25 \%$ xylene glycol, and $30 \%$ glycerol. The $0.8 \%$ agarose was melted in $1 \times$ TAE buffer ( $50 \times$ TAE buffer ( $40 \mathrm{mM}$ Tris acetate, pH 7.5 and $1 \mathrm{mM}$ EDTA) diluted with DEPC-water). Then, $0.5 \mu \mathrm{g} / \mathrm{mL}$ ethidium bromide (EtBr) was added when the mixture cooled to around $60{ }^{\circ} \mathrm{C}$. The gel medium was placed onto horizontal gel trays with combs to generate vertical gel loading pockets for solidification. The polymerized gels were placed into an RNase-free gel tank with $1 \times$ TAE buffer. Next, $2 \mu \mathrm{L}$ of RNA was placed into the wells using $6 \times$ loading buffer $(0.25 \%(w / v)$ bromophenol blue, $0.25 \%(w / v)$ xylene glycol, and 30\% (v/v) glycerol). The RNA was separated on the gels at $100 \mathrm{~V}$ for $1 \mathrm{~h}$. The fluorogram was documented photographically using a gel documentation system (Alpha Imager, Bengaluru, Karnataka, India).

\subsection{4. cDNA Synthesis}

An M-MuLV Reverse Transcriptase kit was used to obtain cDNA from whole RNA (Genei, Bangalore, India). The kit's components were thawed, combined, and briefly centrifuged before being stored on ice. The following reagents were introduced in order to a sterile, nuclease-free tube on ice: $5 \mathrm{~g}$ of total RNA, $1 \mu \mathrm{L}$ of oligo (dT) primer, and $12 \mu \mathrm{L}$ of nuclease-free water. The reagents were gently mixed, centrifuged at $2500 \mathrm{rpm}$, and incubated at $65^{\circ} \mathrm{C}$ for $5 \mathrm{~min}$. The tube was chilled on ice before being spun down and then returned to the ice. Next, $4 \mu \mathrm{L}$ of $5 \times$ reaction buffer, $1 \mu \mathrm{L}$ of RNase inhibitor, $2 \mu \mathrm{L}$ of $10 \mathrm{mM}$ dNTP Mix, and $1 \mu \mathrm{L}$ of M-MuLV Reverse Transcriptase, made up to a total volume of $20 \mu \mathrm{L}$ were mixed gently and centrifuged at $2500 \mathrm{rpm}$ for $5 \mathrm{~min}$. The samples were incubated for 
60 min at $42{ }^{\circ} \mathrm{C}$ for gene-specific primed cDNA synthesis. The process was stopped after 5 min of heating at $70^{\circ} \mathrm{C}$.

\subsubsection{RT-PCR Analysis}

Primer pairs specific to chili defensive genes were designed and used. Primers for chili ubiquitin E3 gene (NCBI accession number XM_016720450.1) cDNA (sense, 5'-GTCCATCTGCTCTCTGTTG-3'; antisense, 5'-ACCCCAAGCACAATAAGAC-3') were used as an internal control. All RT-PCR experiments were conducted in three replicates. Quantitative RT-PCR analysis was conducted to profile the expression of selected defensive genes. The expression of chili genes representing the upstream and downstream pathogenesis response system was profiled by qRT-PCR after infection of chili seedlings with $R$. solanacearum and rhizobacteria. The expression levels of Lox2, UBI-3, POD, SOD, WRKYa, PAL1, DEF1, CAT2, HSFC1, WRKY40, PAL, NPRI, and UBI-3 genes were determined at $48 \mathrm{~h}$ post inoculation using real-time $\mathrm{PCR}$, by establishing a gradient concentration using $40 \mathrm{nM}$ of primers and 10-100 ng of cDNA. The PCR conditions involved initial activation at $95^{\circ} \mathrm{C}$ for $5 \mathrm{~min}$, denaturation at $95^{\circ} \mathrm{C}$ for $30 \mathrm{~s}$, and combined annealing/extension at $60{ }^{\circ} \mathrm{C}$ for $30 \mathrm{~s}$. The PCR product was melted at $72{ }^{\circ} \mathrm{C}$ for $1 \mathrm{~min}$ and then ramped from 72 to $98^{\circ} \mathrm{C}$ by $1{ }^{\circ} \mathrm{C}$ every $5 \mathrm{~s}$.

The following formula was used to compute the relative gene expression in terms of fold change: fold change $=2-\Delta \Delta \mathrm{Ct}$ where, $\Delta \mathrm{Ct}=\mathrm{Ct}$, target $-\mathrm{Ct}$, normalizer, and $\Delta \Delta \mathrm{Ct}=\Delta \mathrm{Ct}$, stimulated $-\Delta \mathrm{Ct}$, control.

\subsection{Statistical Analysis}

All experiments were performed in a completely randomized design with three replicates. Prior to statistical analysis, all bacterial counts were logarithmically converted. Oneand two-way analyses of variance (ANOVAs) using SAS (SAS Institute 1998) were applied to evaluate significant differences between treatments at a significance level of 0.05 . Tukey's post hoc multiple comparison test [32] was used to examine differences between experimental treatments. The values of enzyme activities were expressed as the means of three measurements $( \pm \mathrm{SE})$ from three plants under the same treatment.

\section{Results}

\subsection{Inhibitory Effect of Volatile Compounds Produced by Rhizobacterial Isolates of Chili against} Ralstonia solanacearum

We obtained evidence that PGPRs were involved in inhibiting the growth of $R$. solonacearum in our previous study [33]. Nevertheless, to examine how microbial volatile compounds can impact the growth of $R$. solonacearum cells, we examined the pathogen growth under the influence of rhizobacteria producing volatile compounds. It was found after 7 days of observation that the maximum inhibition was achieved by the PDS1 isolate (72.24\%), followed by KA9 (68.38\%), BDS1 (66.04\%), UK2 (64.35\%), and UK4 (61.48\%) (Table 1). Electron microscopy revealed that most of the R. solanacearum cells became irregularly shaped due to disintegration of the cell wall, with most of the cells bursting and dying in the presence of volatile compounds secreted from the PGPR strains (Figure 3).

\subsection{Analysis of Volatile Compounds Produced by Rhizobacteria under In Vitro Conditions}

A comparative study of the production of volatile compounds by isolates Pseudomonas fluorescens PDS1 and Bacillus subtilis KA9 was conducted using the GC-MS method. A total of 63 compounds were identified from the GC-MS analysis. The predominant compounds produced by Bacillus subtilis strain KA9 in terms of peak area were 2-ethyl-3,6-dimethyl pyrazine (22.59\%), 3-hydroxy-2-butanone (acetoin) (13.68\%), benzaldehyde $(0.32 \%)$, cycloheptasiloxane $(0.73 \%)$, 2-methyl pyrazine $(15.95 \%)$, diethyl phthalate $(7.75 \%)$, cyclohexanone $(0.22 \%)$, 3-isobutyl hexahydropyrrolo (3.96\%), 4-hydroxy5-methyl-2-hexanone $(0.43 \%), 2,4$-di-tert-butylphenol $(0.47 \%)$, hexadecane $(0.98 \%)$, hexahydropyrrolo, $(1,2, \alpha)$ pyrazine-1,4-dione (4.78\%), isoamyl alcohol $(10.07 \%)$, and disulfide 
dimethyl $(2.87 \%)$. The predominant compounds produced by Pseudomonas fluorescens strain PDS-1 were 2-ethyl-3,6-dimethyl pyrazine (28.07\%), 3-hydroxy-2-butanone (acetoin) $(10.02 \%)$, benzaldehyde $(0.43 \%)$, 2-methyl pyrazine $(24.40 \%)$, 1-undecene $(7.10 \%)$, diethyl phthalate $(7.10 \%)$, cyclohexanone $(0.20 \%)$, 3-isobutyl hexahydropyrrolo $(0.91 \%)$, 4hydroxy-5-methyl-2-hexanone ( $0.87 \%)$, 2,4-di-tert-butylphenol $(0.46 \%)$, hexadecane $(0.23 \%)$, hexahydropyrrolo, $(1,2, \alpha)$ pyrazine-1,4-dione $(3.23 \%)$, isoamyl alcohol $(20.09 \%)$, and disulfide dimethyl $(6.34 \%)$. Most compounds were benzene derivatives, with pyrazine-1,4dione, 3-hydroxy-2-butanone (acetoin), 2-ethyl 3, 6-dimethyl pyrazine, 2-methyl pyrazine, 2-ethyl-3,6-dimethyl pyrazine, and diethylphthalate having peak areas between $2.6 \%$ and $28.07 \%$ (Figure 4 and Supplementary Table S11). Other volatile molecules were also present but observed in lower concentrations, as indicated by the smaller peak areas (Supplementary Figures S1 and S2).

Table 1. Inhibitory effect of volatile compounds produced by rhizobacterial isolates of chili against Ralstonia solanacearum under in vitro conditions.

\begin{tabular}{ccc}
\hline Treatments & Colony Growth $\mathbf{( m m )}$ & Inhibition $\mathbf{( \% )}$ \\
\hline PDS1 + R & 24.98 & 72.24 \\
UK2 + R & 32.08 & 64.35 \\
UK4 + R & 34.67 & 61.48 \\
BDS1 + R & 30.56 & 66.04 \\
KA9 + R & 28.45 & 68.38 \\
Control & 90.00 & - \\
SEM $( \pm)$ & 1.41 & \\
CD at $1 \%$ & 4.58 & \\
\hline
\end{tabular}

PDS1: Pseudomonas fluorescens; UK2: Bacillus amyloliquefaciens; UK4: Bacillus cereus; BDS1: Bacillus subtilis; KA9: Bacillus subtilis; R: Ralstonia solanacearum.

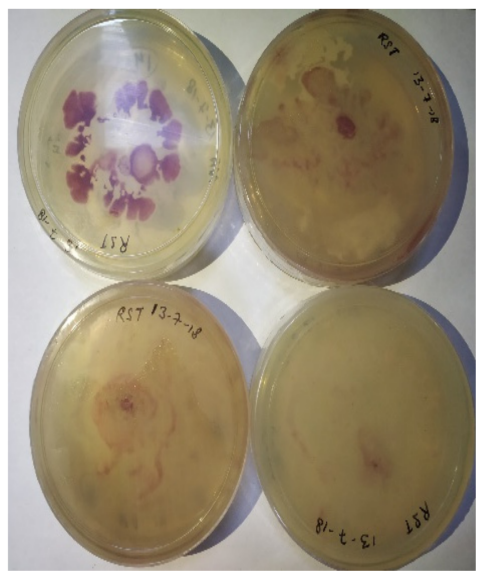

(a)

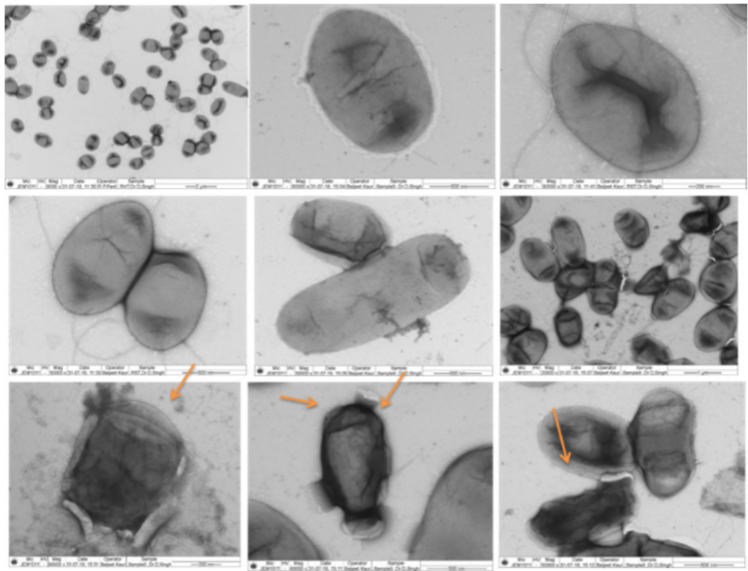

(b)

Figure 3. (a) Inhibitory effect of volatile compounds produced by PGPRs of chili against Ralstonia solanacearum under in vitro conditions. (b) TEM images revealing disruption of $R$. solanacearum cells due to volatile compounds produced by rhizobacteria.

By analyzing these mass spectra to that in the NIST Mass Spectral Library (probabilitybased similarity $>85 \%$ ), the chemicals potentially produced by rhizobacteria treatments were identified. The relative content of each compound is shown as a mean $(n=3)$. The peak area of each compound was calculated as a percentage relative to the total peak area of all volatile organic compounds in a particular treatment. Several minor peaks were not included. 




Figure 4. Graph showing gas chromatography-mass spectrometry (GC-MS) profile of major volatile organic compounds (VOCs) produced by rhizobacteria against $R$. solanacearum under in vitro conditions.

\subsection{Effect of Volatile Compounds Produced by Rhizobacteria in the Induction of Defensive} Enzymes against Bacterial Wilt Caused by R. solanacearum in Chili

3.3.1. Peroxidase Activity (PO)

\section{Leaves}

Peroxidase activity was measured as the change in OD per minute per milligram of protein. The maximum PO activity was observed in treatment T6 (KA9 + PDS1 + RS) $\left(0.090 \pm 0.002 \Delta \mathrm{OD} \cdot \mathrm{min}^{-1} \cdot \mathrm{mg}^{-1}\right.$ protein $)$ followed by T5 $\left(0.080 \pm 0.002 \Delta \mathrm{OD} \cdot \mathrm{min}^{-1} \cdot \mathrm{mg}^{-1}\right.$ protein) at 48 hapi in leaf tissue. At $24 \mathrm{~h}$ after pathogen inoculation, the maximum $\mathrm{PO}$ activity was observed in T6 $\left(0.056 \pm 0.003 \Delta \mathrm{OD} \cdot \mathrm{min}^{-1} \cdot \mathrm{mg}^{-1}\right.$ protein) followed by T5 $\left(0.049 \pm 0.002 \Delta\right.$ OD $\cdot \mathrm{min}^{-1} \cdot \mathrm{mg}^{-1}$ protein $)$ and T4 $\left(0.046 \pm 0.003 \Delta \mathrm{OD} \cdot \mathrm{min}^{-1} \cdot \mathrm{mg}^{-1}\right.$ protein $)$ as compared to the pathogen-treated plant $\left(0.029 \pm 0.002 \Delta \mathrm{OD} \cdot \mathrm{min}^{-1} \cdot \mathrm{mg}^{-1}\right.$ protein). At 72 hapi, the maximum PO activity was observed in T6 $\left(0.064 \pm 0.002 \Delta \mathrm{OD} \cdot \mathrm{min}^{-1} \cdot \mathrm{mg}^{-1}\right.$ protein $)$ followed by T5 $\left(0.058 \pm 0.002 \Delta \mathrm{OD} \cdot \mathrm{min}^{-1} \cdot \mathrm{mg}^{-1}\right.$ protein $)$ and T3 $\left(0.061 \pm 0.002 \Delta \mathrm{OD} \cdot \mathrm{min}^{-1} \cdot \mathrm{mg}^{-1}\right.$ protein) as compared to the pathogen-treated plant $\left(0.043 \pm 0.002 \Delta\right.$ OD $\cdot \mathrm{min}^{-1} \cdot \mathrm{mg}^{-1}$ protein) (Supplementary Table S1 and Figure 5b).

The PO activity was increased in all treatments until 48 hapi, after which it declined significantly (Supplementary Table S1). Plants treated with rhizobacteria had higher PO activity than untreated plants (Figure $5 \mathrm{~b}$ ). Furthermore, the R. solanacearum-treated plants had considerably higher PO activity at 48 h, i.e., $0.059 \pm 0.002$, than the untreated plants. However, P. fluorescens PDS1 produced volatile compounds that induced higher PO activity than B. subtilis KA9.

Roots

PO activity is expressed as the unit change in absorbance per minute per milligram of protein $\left(\Delta \mathrm{OD} \cdot \mathrm{min}^{-1} \cdot \mathrm{mg}^{-1}\right.$ protein). $\mathrm{PO}$ activity in roots expressed similar trends to those seen in leaves, with the maximum activity observed in T6 $\left(0.0092 \pm 0.002 \Delta \mathrm{OD} \cdot \mathrm{min}^{-1} \cdot \mathrm{mg}^{-1}\right.$ protein) followed by T5 $\left(0.0082 \pm 0.002 \Delta \mathrm{OD} \cdot \mathrm{min}^{-1} \cdot \mathrm{mg}^{-1}\right.$ protein). At $24 \mathrm{~h}$ after pathogen inoculation, the maximum PO activity was observed in T6 $\left(0.0073 \pm 0.021 \Delta \mathrm{OD} \cdot \mathrm{min}^{-1} \cdot \mathrm{mg}^{-1}\right.$ protein) followed by $\mathrm{T} 4\left(0.0060 \pm 0.027 \Delta \mathrm{OD} \cdot \mathrm{min}^{-1} \cdot \mathrm{mg}^{-1}\right.$ protein $)$ as compared to the pathogen-treated control $\left(0.0052 \pm 0.027 \Delta \mathrm{OD} \cdot \mathrm{min}^{-1} \cdot \mathrm{mg}^{-1}\right.$ protein). At $48 \mathrm{hapi}$, the 
maximum PO activity was observed in T6 $\left(0.0092 \pm 0.020 \Delta \mathrm{OD} \cdot \mathrm{min}^{-1} \cdot \mathrm{mg}^{-1}\right.$ protein $)$ followed by T5 $\left(0.0082 \pm 0.020 \Delta \mathrm{OD} \cdot \mathrm{min}^{-1} \cdot \mathrm{mg}^{-1}\right.$ protein $)$ as compared to the pathogentreated control $\left(0.0077 \pm 0.020 \Delta \mathrm{OD} \cdot \mathrm{min}^{-1} \cdot \mathrm{mg}^{-1}\right.$ protein). At 72 hapi, the maximum PO activity was observed in $\mathrm{T} 3\left(0.0050 \pm 0.031 \Delta \mathrm{OD} \cdot \mathrm{min}^{-1} \cdot \mathrm{mg}^{-1}\right.$ protein $)$ followed by $\mathrm{T} 4$ $\left(0.0043 \pm 0.039 \Delta \mathrm{OD} \cdot \mathrm{min}^{-1} \cdot \mathrm{mg}^{-1}\right.$ protein $)$ as compared to the pathogen-treated control $\left(0.0036 \pm 0.021 \Delta \mathrm{OD} \cdot \mathrm{min}^{-1} \cdot \mathrm{mg}^{-1}\right.$ protein) (Supplementary Table S2 and Figure 5b).
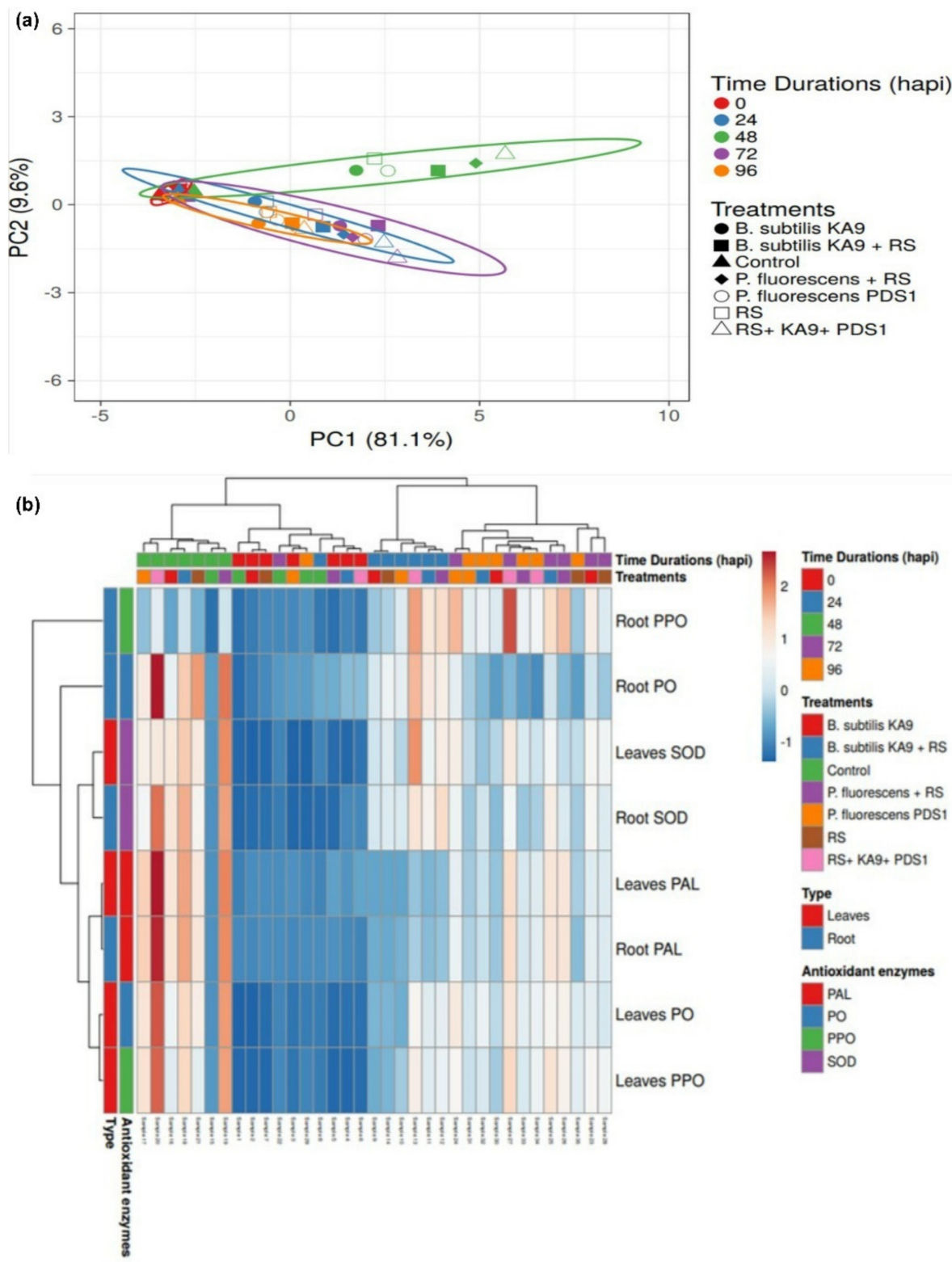

Figure 5. (a). Principal component analysis of effect of volatile compounds produced by biocontrol agents on the induction of defensive enzyme activities in chili leaves and roots against $R$. solanacearum in glasshouse conditions. (b) Heatmap showing the effect of volatile compounds produced by biocontrol agents on the induction of PAL, PO, PPO and SOD activities in chili leaves and roots against $R$. solanacearum at different time intervals in glasshouse conditions.

The PO activity in chili roots increased for $48 \mathrm{~h}$ following pathogen inoculation, before decreasing significantly (Figure 5). Only plants treated with rhizobacteria had higher PO activity than untreated plants (Supplementary Table S2). Furthermore, plants treated with $R$. solanacearum only showed an increase in PO activity after $48 \mathrm{~h}$, i.e., $0.0077 \pm 0.020 \Delta \mathrm{OD} \cdot \mathrm{min}^{-1} \cdot \mathrm{mg}^{-1}$ protein, which was substantially higher than in untreated plants. PO activity was more significant 
in P. fluorescens PDS1 than in B. subtilis KA9. According to the principal component analysis in glasshouse conditions, the effects of volatile compounds produced by biocontrol agents on the induction of peroxidase (PO) activity in chili leaves and roots against Ralstonia solanacearum were greatest for treatment T6 at $48 \mathrm{~h}$ (0.055 and 0.051, respectively). However, the induction of this defense enzyme was slightly higher in leaves (1.07-fold) than in roots (Figure 5a).

\subsubsection{Polyphenol Oxidase Activity (PPO)}

Leaves

The polyphenol oxidase activity was measured as the change in absorbance per minute per milligram of protein $\left(\Delta \mathrm{OD} \cdot \mathrm{min}^{-1} \cdot \mathrm{mg}^{-1}\right.$ protein). The maximum PPO activity at 24 hapi was observed in T6 $\left(0.055 \pm 0.001 \Delta \mathrm{OD} \cdot \mathrm{min}^{-1} \cdot \mathrm{mg}^{-1}\right.$ protein $)$ followed by T5 $\left(0.047 \pm 0.001 \Delta \mathrm{OD} \cdot \mathrm{min}^{-1} \cdot \mathrm{mg}^{-1}\right.$ protein $)$ as compared to the pathogen-treated plant $\left(0.027 \pm 0.001 \Delta \mathrm{OD} \cdot \mathrm{min}^{-1} \cdot \mathrm{mg}^{-1}\right.$ protein). At 48 hapi, the maximum PPO activity was observed in T6 $\left(0.082 \pm 0.001 \Delta \mathrm{OD} \cdot \mathrm{min}^{-1} \cdot \mathrm{mg}^{-1}\right.$ protein $)$ followed by T5 $\left(0.074 \pm 0.001 \Delta \mathrm{OD} \cdot \mathrm{min}^{-1} \cdot \mathrm{mg}^{-1}\right.$ protein). At 72 hapi, the maximum PPO activity was observed in T6 $\left(0.064 \pm 0.003 \Delta \mathrm{OD} \cdot \mathrm{min}^{-1} \cdot \mathrm{mg}^{-1}\right.$ protein) and T4 $\left(0.060 \pm 0.003 \Delta \mathrm{OD} \cdot \mathrm{min}^{-1} \cdot \mathrm{mg}^{-1}\right.$ protein) as compared to the pathogentreated plant $\left(0.049 \pm 0.002 \Delta \mathrm{OD} \cdot \mathrm{min}^{-1} \cdot \mathrm{mg}^{-1}\right.$ protein) (Supplementary Table S3 and Figure 5b).

PPO activity increased in all treatments until $48 \mathrm{~h}$ after pathogen inoculation, before decreasing significantly, except for the pathogenic treatment T7 (Figure 5b). Plants treated with rhizobacteria had higher PPO activity than untreated plants (Supplementary Table S3). Furthermore, only $R$. solanacearum-treated plants showed a substantial increase in PPO activity at 72 hapi, i.e., $0.049 \pm 0.002$, compared to untreated plants. PPO activity was more increased by volatile molecules generated by P. fluorescens PDS1 than by B. subtilis KA9.

Roots

Polyphenol oxidase activity was measured as the change in absorbance per minute per milligram of protein $\left(\Delta \mathrm{OD} \cdot \mathrm{min}^{-1} \cdot \mathrm{mg}^{-1}\right.$ protein). At $72 \mathrm{~h}$ after pathogen inoculation, treatment T6 $\left(0.0075 \pm 0.034 \Delta \mathrm{OD} \cdot \mathrm{min}^{-1} \cdot \mathrm{mg}^{-1}\right.$ protein $)$ had the highest PPO activity in root tissues, followed by T3 $\left(0.0064 \pm 0.033 \Delta \mathrm{OD} \cdot \mathrm{min}^{-1} \cdot \mathrm{mg}^{-1}\right.$ protein $)$. The maximum PPO activity was observed in T6, where volatile compounds produced by two rhizobacteria were inoculated $\left(0.0067 \pm 0.030 \Delta \mathrm{OD} \cdot \mathrm{min}^{-1} \cdot \mathrm{mg}^{-1}\right.$ protein) followed by T5 $\left(0.0058 \pm 0.032 \Delta \mathrm{OD} \cdot \mathrm{min}^{-1} \cdot \mathrm{mg}^{-1}\right.$ protein $)$ as compared to the pathogen-treated plant $\left(0.0035 \pm 0.026 \Delta \mathrm{OD} \cdot \mathrm{min}^{-1} \cdot \mathrm{mg}^{-1}\right.$ protein $)$ at 24 hapi. The maximum PPO activity was observed in T6 $\left(0.0043 \pm 0.028 \Delta \mathrm{OD} \cdot \mathrm{min}^{-1} \cdot \mathrm{mg}^{-1}\right.$ protein $)$ followed by T5 $\left(0.0038 \pm 0.031 \Delta \mathrm{OD} \cdot \mathrm{min}^{-1} \cdot \mathrm{mg}^{-1}\right.$ protein $)$ and $\mathrm{T} 4\left(0.0038 \pm 0.027 \Delta \mathrm{OD} \cdot \mathrm{min}^{-1} \cdot \mathrm{mg}^{-1}\right.$ protein) (Supplementary Table S4 and Figure 5b). The PPO activity in chili roots was increased in all treatments until $72 \mathrm{~h}$ after pathogen inoculation, before declining significantly (Figure 5b). The PPO activity due to the production of VOCs by rhizobacteria-treated plants was higher than that of untreated plants (Supplementary Table S4). Furthermore, plants treated with $R$. solanacearum only showed an increase in PPO activity after $72 \mathrm{~h}$, with $0.0042 \pm 0.020 \Delta \mathrm{OD} \cdot \mathrm{min}^{-1} \cdot \mathrm{mg}^{-1}$ protein, which was considerably greater than that in untreated plants. PO activity was greater in P. fluorescens PDS1 than in B. subtilis KA9. In glasshouse conditions, a mean value comparison on the effect of volatile compounds produced by biocontrol agents under glasshouse conditions, treatment $\mathrm{T} 6$ recorded the maximum polyphenol oxidase (PPO) enzyme activities in roots and leaves of chilli against $R$. solanacearum with 0.0050 and 0.052 respectively. This defense related enzyme was activated 10.40-fold more in the leaves than the roots (Figure 5a).

\subsubsection{Superoxide Dismutase (SOD)}

Leaves

The activity of superoxide dismutase was measured as the change in absorbance per minute per milligram of protein. When compared to untreated healthy plants, SOD activity increased in all treatments in the current study. At 24 hapi, the maximum SOD 
activity was observed due to the volatile compounds produced by rhizobacteria in T6 $\left(0.081 \pm 0.002 \Delta \mathrm{OD} \cdot \mathrm{min}^{-1} \cdot \mathrm{mg}^{-1}\right.$ protein $)$ followed by T5 $\left(0.062 \pm 0.003 \Delta \mathrm{OD} \cdot \mathrm{min}^{-1} \cdot \mathrm{mg}^{-1}\right.$ protein) as compared to the pathogen-treated plant $\left(0.051 \pm 0.002 \Delta \mathrm{OD} \cdot \mathrm{min}^{-1} \cdot \mathrm{mg}^{-1}\right.$ protein). At 48 hapi, the maximum SOD activity was observed in T5 $\left(0.082 \pm 0.004 \Delta \mathrm{OD} \cdot \mathrm{min}^{-1} \cdot \mathrm{mg}^{-1}\right.$ protein) followed by T4 $\left(0.072 \pm 0.002 \Delta \mathrm{OD} \cdot \mathrm{min}^{-1} \cdot \mathrm{mg}^{-1}\right.$ protein $)$. At 72 hapi, the maximum SOD activity was observed in T6 $\left(0.063 \pm 0.003 \Delta \mathrm{OD} \cdot \mathrm{min}^{-1} \cdot \mathrm{mg}^{-1}\right.$ protein $)$ followed by T3 $\left(0.062 \pm 0.003 \Delta \mathrm{OD} \cdot \mathrm{min}^{-1} \cdot \mathrm{mg}^{-1}\right.$ protein $)$ as compared to the pathogen-treated control (0.056 $\pm 0.004 \Delta \mathrm{OD} \cdot \mathrm{min}^{-1} \cdot \mathrm{mg}^{-1}$ protein) (Supplementary Table S5 and Figure $5 \mathrm{~b}$ ).

SOD activity was enhanced in all treatments until $48 \mathrm{~h}$ after pathogen inoculation, except T6, before considerably decreasing (Figure 5b). SOD activity was higher in rhizobacteriatreated plants than in untreated plants (Supplementary Table S5). Furthermore, plants treated with only $R$. solanacearum showed an increase in SOD activity after $48 \mathrm{~h}, 0.063 \pm 0.003$, which was substantially higher than in untreated plants. The volatile compounds generated by B. subtilis KA9 treatment increased SOD activity more than those generated by $P$. fluorescens PDS1.

Roots

Maximum SOD activity at 24 hapi was observed due to the volatile compounds produced by rhizobacteria in T6 $\left(0.0091 \pm 0.026 \Delta \mathrm{OD} \cdot \mathrm{min}^{-1} \cdot \mathrm{mg}^{-1}\right.$ protein $)$ followed by $\mathrm{T} 5\left(0.0085 \pm 0.025 \Delta \mathrm{OD} \cdot \mathrm{min}^{-1} \cdot \mathrm{mg}^{-1}\right.$ protein $)$ in the roots of chili plant. The maximum SOD activity at 48 hapi was observed in T5 $\left(0.0075 \pm 0.029 \Delta \mathrm{OD} \cdot \mathrm{min}^{-1} \cdot \mathrm{mg}^{-1}\right.$ protein $)$ followed by T6 $\left(0.0072 \pm 0.031 \Delta \mathrm{OD} \cdot \mathrm{min}^{-1} \cdot \mathrm{mg}^{-1}\right.$ protein $)$ as compared to the pathogentreated control $\left(0.0056 \pm 0.032 \Delta \mathrm{OD} \cdot \mathrm{min}^{-1} \cdot \mathrm{mg}^{-1}\right.$ protein $)$. At 72 hapi, the maximum SOD activity was observed in $\mathrm{T} 4\left(0.0068 \pm 0.030 \Delta \mathrm{OD} \cdot \mathrm{min}^{-1} \cdot \mathrm{mg}^{-1}\right.$ protein $)$ followed by T2 $\left(0.0064 \pm 0.031 \Delta \mathrm{OD} \cdot \mathrm{min}^{-1} \cdot \mathrm{mg}^{-1}\right.$ protein $)$ as compared to the pathogen-treated plant $\left(0.0056 \pm 0.031 \Delta \mathrm{OD} \cdot \mathrm{min}^{-1} \cdot \mathrm{mg}^{-1}\right.$ protein) (Supplementary Table S6 and Figure $\left.5 \mathrm{~b}\right)$.

The SOD activity in chili roots increased until $28 \mathrm{~h}$ after pathogen inoculation in all treatments, before decreasing dramatically (Figure 6). Dual rhizobacteria-treated plants had higher SOD activity than single-rhizobacteria-treated and untreated plants (Supplementary Table S6). Furthermore, plants treated with only $R$. solanacearum showed a substantial increase in SOD activity after $48 \mathrm{~h}$, i.e., $0.0065 \pm 0.026 \Delta \mathrm{OD} \cdot \mathrm{min}^{-1} \cdot \mathrm{mg}^{-1} \mathrm{pro}^{-}$ tein, compared to untreated plants. However, there was no significant difference between $P$. fluorescens PDS1 and B. subtilis KA9 in terms of the induction of SOD enzyme activity in the root tissue of chili plants.

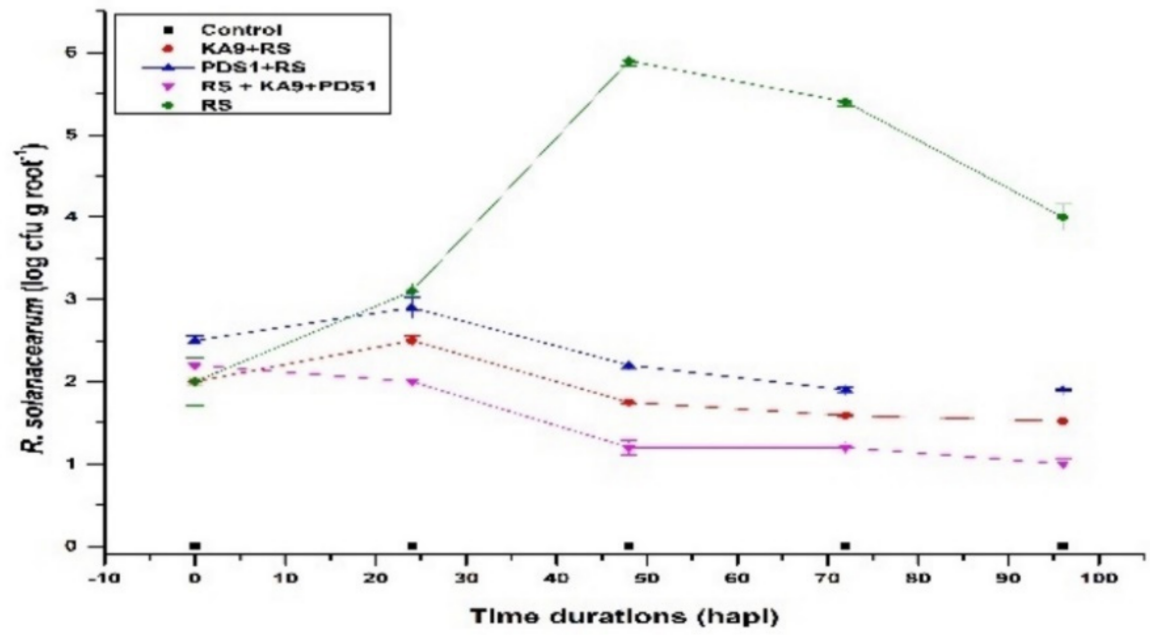

Figure 6. Population of R. solanacearum in the rhizospheric zone of the soil with chili plants under different treatments in glasshouse conditions.

A mean value comparison on the effect of volatile compounds produced by biocontrol agents under glasshouse conditions, treatment T6 recorded the maximum SOD enzyme 
activities in roots and leaves of chilli against $R$. solanacearum with 0.0057 and 0.052 respectively. This defense related enzyme was activated 9.12-fold -fold more in the leaves than the roots (Figure 5a).

\subsubsection{Phenyl Ammonia Lyase (PAL)}

Leaves

Phenyl ammonia lyase activity is expressed in $\mu \mathrm{mol} t$-cinnamate $\cdot \mathrm{min}^{-1} \cdot \mathrm{g}^{-1} \mathrm{FW}$. The present study found that PAL activity increased in all treatments, compared to unchallenged untreated healthy control plants. Overall, maximum PAL activity was observed due to volatile compounds produced by rhizobacteria in $\mathrm{T} 6\left(312.667 \pm 2.64 \mu \mathrm{mol} t\right.$-cinnamate $\cdot \mathrm{min}^{-1} \cdot \mathrm{g}^{-1}$ $\mathrm{FW})$ followed by $\mathrm{T} 5\left(265.00 \pm 1.64 \mu \mathrm{mol} t\right.$-cinnamate $\left.\cdot \mathrm{min}^{-1} \cdot \mathrm{g}^{-1} \mathrm{FW}\right)$ at 48 hapi. At 24 hapi, the maximum PAL activity was observed in T6 $\left(88.33 \pm 3.24 \mu \mathrm{mol} \cdot \mathrm{min}^{-1} \cdot \mathrm{g}^{-1} \mathrm{FW}\right)$ and T5 $\left(84.333 \pm 1.27 \mu \mathrm{mol} \cdot \mathrm{min}^{-1} \cdot \mathrm{g}^{-1} \mathrm{FW}\right)$ as compared to the pathogen-treated control $\left(63.666 \pm 2.25 \mu \mathrm{mol} \cdot \mathrm{min}^{-1} \cdot \mathrm{g}^{-1} \mathrm{FW}\right)$. At $72 \mathrm{hapi}$, the maximum PAL activity was observed in T6 $\left(207.000 \pm 3.12 \mu \mathrm{mol} \cdot \mathrm{min}^{-1} \cdot \mathrm{g}^{-1} \mathrm{FW}\right)$ followed by T5 $\left(192.00 \pm 1.64 \mu \mathrm{mol} \cdot \mathrm{min}^{-1} \cdot \mathrm{g}^{-1}\right.$ $\mathrm{FW})$ and $\mathrm{T} 4\left(191.933 \pm 2.34 \mu \mathrm{mol} \cdot \mathrm{min}^{-1} \cdot \mathrm{g}^{-1} \mathrm{FW}\right)$ as compared to the pathogen-treated plant (134.333 $\pm 2.21 \mu \mathrm{mol} \cdot \mathrm{min}^{-1} \cdot \mathrm{g}^{-1} \mathrm{FW}$ ) (Supplementary Table S7 and Figure 5b). The PAL activity was increased in all treatments up to 48 hapi, after which it declined significantly (Figure 5a). The PAL activity due to the volatile compounds produced by rhizobacteriatreated plants was higher than that in untreated plants (Supplementary Table S7). After $48 \mathrm{~h}, R$. solanacearum-treated plants exhibited a significantly increased in PAL activity $(188.667 \pm 3.24)$ in comparison to the untreated plants. However, the volatile produced by $P$. fluorescens PDS1 enhanced the induction of PAL activity in the leaves of chilli cv. PusaJwala as compared to B. subtilis KA9.

Roots

Overall, the maximum PAL activity was observed in treatment T6 $(299.67 \pm 3.40 \mu \mathrm{mol}$ $t$-cinnamate $\left.\cdot \mathrm{min}^{-1} \cdot \mathrm{g}^{-1} \mathrm{FW}\right)$ followed by T5 $\left(254.67 \pm 3.16 \mu \mathrm{mol} t\right.$-cinnamate $\cdot \mathrm{min}^{-1} \cdot \mathrm{g}^{-1}$ FW) at 48 hapi in roots of chili cv. Pusa Jwala. At 24 hapi, the maximum PAL activity was observed in T6 $\left(88.00 \pm 2.00 \mu \mathrm{mol} \cdot \mathrm{min}^{-1} \cdot \mathrm{g}^{-1} \mathrm{FW}\right)$ and T5 $\left(80.33 \pm 2.17 \mu \mathrm{mol} \cdot \mathrm{min}^{-1} \cdot \mathrm{g}^{-1} \mathrm{FW}\right)$ as compared to the pathogen-treated plant $\left(58.00 \pm 2.86 \mu \mathrm{mol} \cdot \mathrm{min}^{-1} \cdot \mathrm{g}^{-1} \mathrm{FW}\right)$. At 72 hapi, the maximum PAL activity was observed in T6 $\left(199.33 \pm 3.42 \mu \mathrm{mol} \cdot \mathrm{min}^{-1} \cdot \mathrm{g}^{-1} \mathrm{FW}\right)$, as well as T5 $\left(187.00 \pm 2.24 \mu \mathrm{mol} \cdot \mathrm{min}^{-1} \cdot \mathrm{g}^{-1} \mathrm{FW}\right)$ and T4 $\left(185.33 \pm 2.84 \mu \mathrm{mol} \cdot \mathrm{min}^{-1} \cdot \mathrm{g}^{-1} \mathrm{FW}\right)$, followed by T3 $\left(141.67 \pm 2.73 \mu \mathrm{mol} \cdot \mathrm{min}^{-1} \cdot \mathrm{g}^{-1} \mathrm{FW}\right)$ as compared to the pathogen-treated control (124.33 $\pm 2.92 \mu \mathrm{mol} \cdot \mathrm{min}^{-1} \cdot \mathrm{g}^{-1} \mathrm{FW}$ ) (Supplementary Table S8 and Figure 5b).

The PAL activity in chili roots was increased in all treatments up to 48 hapi, after which it declined significantly (Figure $5 b$ ). Volatile compounds produced by dualrhizobacteria-treated plants showed more PAL activity than those produced by individual rhizobacteria-treated plants and untreated plants (Supplementary Table S8). Furthermore, after 48 hapi, $R$. solanacearum-treated plants also showed an increase in PAL activity $\left(184.67 \pm 2.65 \mu \mathrm{mol} \cdot \mathrm{min}^{-1} \cdot \mathrm{g}^{-1} \mathrm{FW}\right)$, which was substantially higher than in untreated plants. Both rhizobacteria produced volatile compounds with potential for inducing PAL enzyme activation. P. fluorescens PDS1, on the other hand, triggered greater PAL activity than B. subtilis KA9. A mean value comparison on the effect of volatile compounds produced by biocontrol agents under glasshouse conditions, treatment $\mathrm{T} 6$ recorded the maximum PAL enzyme activities in roots and leaves of chilli against $R$. solanacearum with 149.80 and 145.80 respectively. This defene related enzyme was activated 1.027-fold more in the root tissues than the leaves (Figure 5a).

\subsection{Colonization Behavior of R. solanacearum in the Rhizospheric Zone of the Soil with Chili Plants}

Populations of R. solanacearum in the rhizospheric zone of the soil were detected using the plate counting method. The population of $R$. solanacearum increased rapidly after inoculation and reached a maximum on $48 \mathrm{~h}\left(5.9 \pm 0.06 \mathrm{logCFU} \cdot \mathrm{g}^{-1}\right.$ root $)$ in the RS treatment, which was significantly greater than in the uninoculated control. A significant 
low population of $R$. solanacearum was observed in the treatments where rhizobacteria were applied with $R$. solanacearum. As the time period increased, there was decline in the microbial population (Figure 6, Supplementary Table S12).

These overall results indicate that B. subtilis KA9 and P. fluorescens PDS1 effectively suppressed the population of $R$. solanacearum and controlled the chili bacterial wilt caused by $R$. solanacearum.

\subsection{GC-MS Analysis of Volatile Compounds Present in Different Treatments of Rhizobacteria}

The separation and identification of volatile compounds from the plastic bottle assembly were achieved using a Shimadzu QP 2000 fitted with an Rtx-5 ms column (30 m $\times 0.25 \mathrm{~mm}$ ) packed with $95 \%$ dimethyl poly siloxane for GC-MS analysis. The mass spectra of the unknown compounds were compared with those of known compounds stored in the NIST011 library. The active constituents, along with their retention time (RT), molecular weight, molecular formulae, and concentration (peak area\%), were determined from the five different rhizobacteria treatments, namely, T2 (B. subtilis KA9), T3 (P. fluorescens PDS1), T4 (B. subtilis KA9 + R. solanacearum), T5 (P. fluorescens $+R$. solanacearum), and T7 (R. solanacearum). Samples were collected from these treatments for GC-MS analysis, which revealed the presence of 257 compounds among all samples. A total of 137 molecules were specifically present in certain treatments, whereas the remaining 120 molecules were common to multiple samples. Furthermore, 13 compounds were common to all treatments (Figure 7, Table 2). Common compounds with their retention time (RT) included azulene (13.64), 1,2,3trimethyl benzene (10.045), cycloheptasiloxane (15.6-20.13), hexamethyl-cyclotrisiloxane (6.095), dodecane (13.74), ethylbenzene (7.05), tetradecane (16.715), undecane (12.035), and other benzene derivatives such as toluene, as well as various hydrocarbons in the form of alkanes and silicone derivatives. Most of these compounds were aromatic in nature, emphasizing the basic metabolic process of the microbes.



Figure 7. Venn diagram showing total number of volatile compounds produced by rhizobacteria and $R$. solanacearum during the induction of defensive enzymes against bacterial wilt caused by $R$. solanacearum in chili. 
Table 2. Gas chromatography-mass spectrometry (GC-MS) profile of common volatile organic compounds (VOCs) produced in all the treatments during the study of rhizobacteria-mediated defensive enzymes in chili.

\begin{tabular}{|c|c|c|c|c|c|c|}
\hline \multirow{2}{*}{$\begin{array}{c}\text { Volatile } \\
\text { Compounds }\end{array}$} & & \multicolumn{5}{|c|}{ Relative Peak Area (\%) } \\
\hline & Retention Time & $\begin{array}{c}\text { T2 } \\
\text { (B. subtilis KA9) }\end{array}$ & $\begin{array}{l}\text { T3 (P. fluo- } \\
\text { rescens PDS1) }\end{array}$ & $\begin{array}{l}\text { T4 (B. subtilis KA9 } \\
+ \text { R. solanacearum) }\end{array}$ & $\begin{array}{l}\text { T5 (P. fluorescens }+ \\
R . \text { solanacearum) }\end{array}$ & $\begin{array}{c}\mathrm{T} 7 \\
\text { (R. solanacearum) }\end{array}$ \\
\hline Azulene & 13.64 & $0.372 \pm 0.22$ & $0.255 \pm 0.25$ & $0.961 \pm 0.32$ & $0.119 \pm 0.55$ & $0.586 \pm 0.22$ \\
\hline $\begin{array}{c}\text { Benzene, } \\
\text { 1,2,3-trimethyl- }\end{array}$ & 10.045 & $0.103 \pm 0.20$ & $0.730 \pm 0.38$ & $0.274 \pm 0.02$ & $0.419 \pm 0.03$ & $0.553 \pm 0.55$ \\
\hline $\begin{array}{l}\text { Cycloheptasiloxane, } \\
\text { tetradecamethyl- }\end{array}$ & 18 & $0.152 \pm 0.45$ & $0.209 \pm 0.22$ & $0.170 \pm 0.02$ & $0.158 \pm 0.52$ & $0.111 \pm 0.02$ \\
\hline $\begin{array}{l}\text { Cyclohexasiloxane, } \\
\text { dodecamethyl- }\end{array}$ & 15.605 & $0.117 \pm 0.44$ & $0.279 \pm 0.42$ & $0.157 \pm 0.52$ & $0.164 \pm 0.32$ & $0.107 \pm 0.40$ \\
\hline $\begin{array}{c}\text { Cyclononasiloxane, } \\
\text { octadecamethyl- }\end{array}$ & 21.975 & $0.680 \pm 0.33$ & $0.196 \pm 0.20$ & $0.123 \pm 0.05$ & $0.177 \pm 0.32$ & $0.124 \pm 0.22$ \\
\hline $\begin{array}{l}\text { Cyclooctasiloxane, } \\
\text { hexadecamethyl- }\end{array}$ & 20.135 & $0.408 \pm 0.42$ & $0.826 \pm 0.50$ & $0.542 \pm 0.22$ & $0.596 \pm 0.02$ & $0.463 \pm 0.33$ \\
\hline $\begin{array}{c}\text { Cyclotrisiloxane, } \\
\text { hexamethyl- }\end{array}$ & 6.095 & $0.461 \pm 0.42$ & $0.617 \pm 0.02$ & $0.286 \pm 0.33$ & $0.386 \pm 0.20$ & $0.346 \pm 0.22$ \\
\hline Dodecane & 13.74 & $0.271 \pm 0.33$ & $0.714 \pm 0.22$ & $0.252 \pm 0.02$ & $0.455 \pm 0.02$ & $0.229 \pm 0.02$ \\
\hline Ethylbenzene & 7.05 & $0.330 \pm 0.22$ & $0.179 \pm 0.33$ & $0.782 \pm 0.22$ & $0.926 \pm 0.44$ & $0.338 \pm 0.22$ \\
\hline Nonane & 7.96 & $0.354 \pm 0.22$ & $0.929 \pm 0.55$ & $0.159 \pm 0.02$ & $0.494 \pm 0.55$ & $0.199 \pm 0.22$ \\
\hline Tetradecane & 16.715 & $0.412 \pm 0.22$ & $0.390 \pm 0.55$ & $0.154 \pm 0.22$ & $0.286 \pm 0.02$ & $0.134 \pm 0.54$ \\
\hline Toluene & 4.675 & $0.584 \pm 0.22$ & $0.218 \pm 0.44$ & $0.290 \pm 0.55$ & $0.123 \pm 0.22$ & $0.202 \pm 0.02$ \\
\hline Undecane & 12.035 & $0.133 \pm 0.04$ & $0.132 \pm 0.33$ & $0.384 \pm 0.02$ & $0.740 \pm 0.02$ & $0.358 \pm 0.42$ \\
\hline
\end{tabular}

The compounds possibly generated by $R$. solanacearum treatments were identified by comparing their mass spectra to those in the NIST Mass Spectral Library (probability-based match $>85 \%$ ). Values are expressed as the means of the relative content of each compound $(n=3)$. The peak area of each compound was calculated as a percentage relative to the total peak area of all volatile organic compounds in a particular treatment. Several minor peaks are not included. RT, retention time. The values after \pm indicate the standard deviations of three replicates.

By analyzing the mass spectra to most in the NIST Mass Spectral Library (probabilitybased similarity $>85$ percent), the chemicals likely produced by various rhizobacterial treatments of B. subtilis KA9 and P. fluorescens PDS1 was identified. The peak area of each compound was calculated as a percentage relative to the total peak area of all volatile organic compounds in a particular treatment. Major compounds such as 2,6-dimethylpyrazine (20.8), 2-methyl-1-butanol (14.3), 4-ethylbenzoic acid, 2-bromo-4-fluorophenyl (17.49), anisole (12), benzaldehyde, 3,5-dimethyl- (13.51), benzothiazole (15.00), butylthiophenol (11.9), methyl butanal (8.2), octanol (12.5), and oxime-, methoxy-phenyl- (8.195) were identified (Table 3, Supplementary Figure S3a,b,d,e).

Table 3. Gas chromatography-mass spectrometry (GC-MS) profile of major volatile organic compounds (VOCs) produced by different treatments of rhizobacteria.

\begin{tabular}{|c|c|c|c|c|c|}
\hline \multirow[b]{2}{*}{ Volatile Compounds } & \multirow[b]{2}{*}{ Retention Time } & \multicolumn{3}{|c|}{ Relative Peak Area (\%) } & \multirow{2}{*}{$\begin{array}{l}\text { T5 (P. fluorescens + } \\
\text { R. solanacearum) }\end{array}$} \\
\hline & & T2 (B. subtilis KA9) & T3 (P. fluorescens PDS1) & $\begin{array}{c}\text { T4 (B. subtilis KA9 + } \\
\text { R. solanacearum) }\end{array}$ & \\
\hline 2,6-Dimethylpyrazine & 20.8 & $3.775061 \pm 0.85$ & $0.558445 \pm 0.03$ & $4.262294 \pm 0.85$ & $0.78169 \pm 0.05$ \\
\hline 2-Methyl-1-butanol & 14.3 & $1.400815 \pm 0.25$ & $0.235084 \pm 0.05$ & $1.876175 \pm 0.55$ & $0.262361 \pm 0.33$ \\
\hline 4-Ethylbenzoic acid, & 17.49 & $0.692943 \pm 0.05$ & $0.203268 \pm 0.04$ & $0.871781 \pm 0.05$ & $0.200583 \pm 0.03$ \\
\hline Anisole & 12 & $0.612489 \pm 0.05$ & $0.621965 \pm 0.05$ & $0.100418 \pm 0.02$ & $0.543554 \pm 0.03$ \\
\hline $\begin{array}{l}\text { Benzaldehyde, } \\
\text { 3,5-dimethyl- }\end{array}$ & 13.51 & $1.046637 \pm 0.55$ & $0.175852 \pm 0.040$ & $0.990622 \pm 0.55$ & $0.169998 \pm 0.04$ \\
\hline Benzothiazole & 15.00 & $2.191521 \pm 0.33$ & $0.049163 \pm 0.004$ & $1.170364 \pm 0.65$ & $0.390761 \pm 0.06$ \\
\hline Butylthiophenol & 11.9 & $0.601659 \pm 0.005$ & $0.264597 \pm 0.005$ & $0.55181 \pm 0.005$ & $0.2175 \pm 0.005$ \\
\hline Methylbutanal & 8.2 & $0.407827 \pm 0.02$ & $0.111012 \pm 0.02$ & $0.534561 \pm 0.02$ & $0.126171 \pm 0.05$ \\
\hline Octanol & 12.5 & $1.023067 \pm 0.22$ & $0.511885 \pm 0.15$ & $0.270572 \pm 0.02$ & $0.407792 \pm 0.04$ \\
\hline $\begin{array}{c}\text { Oxime-, } \\
\text { methoxy-phenyl- }\end{array}$ & 8.195 & $0.325617 \pm 0.33$ & $0.079616 \pm 0.020$ & $0.543481 \pm 0.05$ & $0.072404 \pm 0.005$ \\
\hline
\end{tabular}

The compounds possibly generated by rhizobacterial treatments were identified by comparing their mass spectra to those in the NIST Mass Spectral Library (probability-based match $>85 \%$ ). Values are expressed as the means of the relative content of each compound $(n=3)$. The peak area of each compound was calculated as a percentage relative to the total peak area of all volatile organic compounds in a particular treatment. Several minor peaks are not included. RT, retention time. The values after \pm indicate the standard deviations of three replicates.

The gas chromatography-mass spectrometry (GC-MS) profile of common volatile organic compounds (VOCs) produced by the treatment (T7) with $R$. Solanacearum revealed 
benzene derivatives, different hydrocarbons in the form of alkanes and esters, and carboxylic acids. Most compounds were aromatic in nature, emphasizing the basic metabolic process of $R$. solanacearum (Table 4, Supplementary Figure S3c).

Table 4. Gas chromatography-mass spectrometry (GC-MS) profile of common volatile organic compounds (VOCs) produced by the treatment (T7) with $R$. solanacearum.

\begin{tabular}{|c|c|c|}
\hline Volatile Compounds & Retention Time & $\begin{array}{c}\text { Relative } \\
\text { Peak Area }(\%)\end{array}$ \\
\hline 1,2-Benzenedicarboxylic acid, bis (2-methylpropyl) ester & 8.04 & $0.38 \pm 0.44$ \\
\hline 2,4-Dimethyl-1-heptene & 10.64 & $0.18 \pm 0.03$ \\
\hline 2-Nonenal, $(E)$ - & 12.04 & $0.12 \pm 0.43$ \\
\hline 3-Heptene, 2,2,4,6,6-pentamethyl- & 16 & $0.17 \pm 0.03$ \\
\hline 5-Hepten-2-one, 6-methyl- & 14.64 & $0.80 \pm 0.22$ \\
\hline Benzene, (1,3,3-trimethylnonyl)- & 18.90 & $0.08 \pm 0.05$ \\
\hline Benzene, (1-methylethyl)- & 20.11 & $0.61 \pm 0.33$ \\
\hline Benzene, 1,1'-(1-methylethylidene) bis [4-methyl- & 18.05 & $0.71 \pm 0.05$ \\
\hline Benzene, 1,3-dichloro- & 18.74 & $0.90 \pm 0.22$ \\
\hline Benzene, 1-ethyl-3-methyl- & 9.05 & $0.32 \pm 0.02$ \\
\hline Benzene, propyl- & 6.96 & $0.42 \pm 0.22$ \\
\hline Butyric acid, 2-phenyl-, dec-2-yl ester & 17.15 & $0.55 \pm 0.22$ \\
\hline Decanal & 8.65 & $0.33 \pm 0.03$ \\
\hline Decane, 3,7-dimethyl- & 10.03 & $0.30 \pm 0.03$ \\
\hline Decane, 4-methyl- & 10.08 & $0.28 \pm 0.05$ \\
\hline Dodecane, 2,6,11-trimethyl- & 12.18 & $0.82 \pm 0.05$ \\
\hline Eucalyptol & 6.04 & $0.67 \pm 0.41$ \\
\hline Heptadecane & 2.05 & $0.90 \pm 0.04$ \\
\hline Heptanal & 2.90 & $0.08 \pm 0.03$ \\
\hline Heptane, 2,3-dimethyl- & 2.80 & $0.61 \pm 0.52$ \\
\hline Hexanal & 6.09 & $0.79 \pm 0.03$ \\
\hline Indane & 12.05 & $0.20 \pm 0.02$ \\
\hline Isopropyl myristate & 14.08 & $0.92 \pm 0.02$ \\
\hline Nonanal & 10.30 & $0.12 \pm 0.04$ \\
\hline Nonane, 5-butyl- & 12.08 & $0.98 \pm 0.02$ \\
\hline Octanal & 6.04 & $0.22 \pm 0.03$ \\
\hline Octane & 8.08 & $0.77 \pm 0.05$ \\
\hline Octane, 2,3,6,7-tetramethyl- & 10.14 & $0.90 \pm 0.05$ \\
\hline
\end{tabular}

The compounds possibly generated by $R$. solanacearum treatment were identified by comparing their mass spectra to those in the NIST Mass Spectral Library (probability-based match $>85 \%$ ). Values are expressed as the means of the relative content of each compound $(n=3)$. The peak area of each compound was calculated as a percentage relative to the total peak area of all volatile organic compounds in a particular treatment. Several minor peaks are not included. RT, retention time. The values after \pm indicate the standard deviations of three replicates.

3.6. Expression of Rhizobacteria-Mediated Defense-Related Genes against R. solanacearum in Chili

A total of 12 genes, namely, PAL, POD, SOD, WRKYa, PAL1, DEF-1, CAT-2, WRKY40, HSFC1, LOX2, and NPR1, along with the transcript abundance of ubiquitin E3 as an endogenous control, were chosen to analyze the expression of defense-related genes in the leaf and root tissues of chili. The inoculated tissues of chili plants were harvested at $48 \mathrm{~h}$ post inoculation of rhizobacteria (i.e., Bacillus subtilis and Pseudomonas fluorescens) from the bottom of the apparatus designed to produce volatile compounds that can induce ISR through the root tissues of plants against pathogenic microbe R. solanacearum (Figure 8).

\section{Gene-Specific Primer Amplification of cDNA}

The RT-PCR assay was performed using three replicates of each sample, for which cDNA synthesis was performed separately and independently. Post PCR, both the amplification plot and the melting curve plot were examined for all 12 genes (Figure 9a-d). It can be observed that most genes yielded a single melting curve; those yielding multiple peaks (marked by red arrows) were excluded from the analysis. Ubi3 gave a single peak at $\sim 80^{\circ} \mathrm{C}$, suggesting the cDNA to be of good quality. Similarly, the sigmoidal curve obtained in the 
amplification plot indicated ideal PCR amplification efficiency as single melting curves were observed for various defensive genes. The relative abundance of the transcripts was analyzed by normalizing the transcript abundance data to Ubi3, followed by calibration.

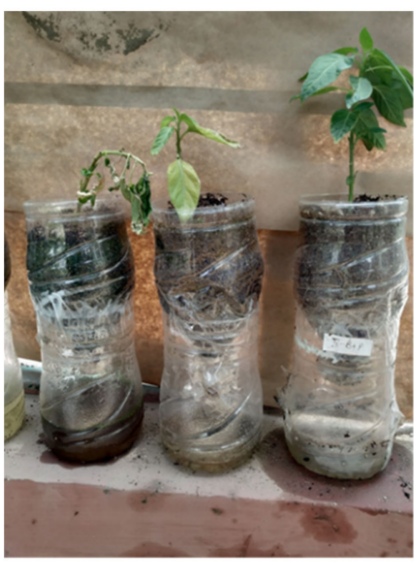

(a)

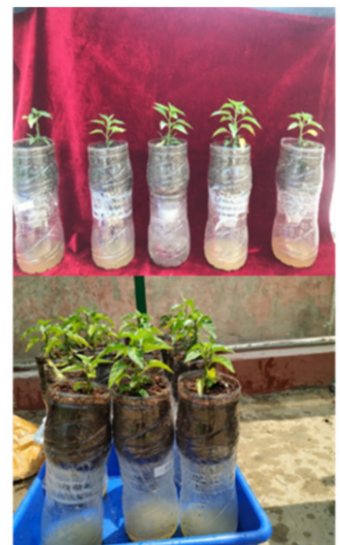

(b)

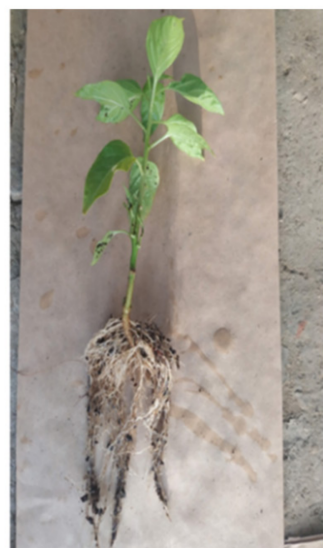

(c)

Figure 8. Effect of volatile compounds produced by rhizobacteria on the induction of defensive enzymes against bacterial wilt caused by $R$. solanacearum in chili in glasshouse conditions: (a) wilted and healthy plants; (b) plastic bottle assembly used to study volatile compounds; (c) chili plant used for growth parameter observations.

The expression of lipoxygenase (LOX), peroxidase (POD), phenyl ammonia lyase (PAL), superoxide dismutase (SOD), catalase (CAT), and defensin gene (DEF) is known to directly reflect ISR at both the transcript and the protein levels. Other genes such as WRKY (WRKYa, WRKY40) and HSF (HSFC) are transcription factors that act as activators or repressors of plant immunity. These genes are also implicated in pathogen-associated molecular pattern-triggered immunity and effector-triggered immunity by influencing gene expression. Furthermore, NPR1 (a nonexpressor of pathogenesis-related genes) contributes to overall plant health when the immune response of the plant is increased. Its expression does not change dramatically upon pathogen infection; hence, its posttranslational modifications are essential. It acts as a transcription cofactor, whose expression changes in leaves because of root-associated bacteria.

3.7. Relative Expression of Defense-Related Genes in the Roots and Leaves of Chili against R. solanacearum in Glasshouse Conditions

3.7.1. PAL (Phenyl Ammonia Lyase) Gene

Ubiquitin 3 was used as an internal control to normalize the reaction, and double delta $\mathrm{Ct}$ analysis was conducted to determine the fold change in expression of the gene product; the values were plotted on a graph. The relative expression of PAL in response to different treatments (RS (R. solanacearum), KA9 + RS (B. subtilis KA9 + R. solanacearum), PDS1 + RS (P. fluorescens PDS1 + R. solanacearum), KA9 + PDS1 + RS (B. subtilis KA9 + P. fluorescens PDS1 + R. solanacearum), BABA (chemical control), and mock inoculated treatments) on susceptible chili cv. Pusa Jwala is represented graphically. In the susceptible cv. Pusa Jwala, the mock treatment was used for calibration, revealing that the BABA treatment at $1000 \mu \mathrm{g} / \mathrm{mL}$ resulted in the highest relative expression of PAL (4.48-fold) at $48 \mathrm{~h}$, followed by KA9 + PDS1 + RS (3.75-fold), KA9 + RS (3.25-fold), PDS1 + RS (3.09-fold), and RS (2.54-fold). These was no significant variation observed in relative expression in response to PDS1 + RS and KA9 + RS treatments. Moreover, the dual rhizobacterial inoculation treatment, i.e., KA9 + PDS1 + RS, led to a significant variation compared to other treatments. Upregulation of defensive gene PAL was found in all treatments as compared to UBI3 (Figure 10a,b) (Supplementary Table S9). 




A



C



B

Molt:Curve

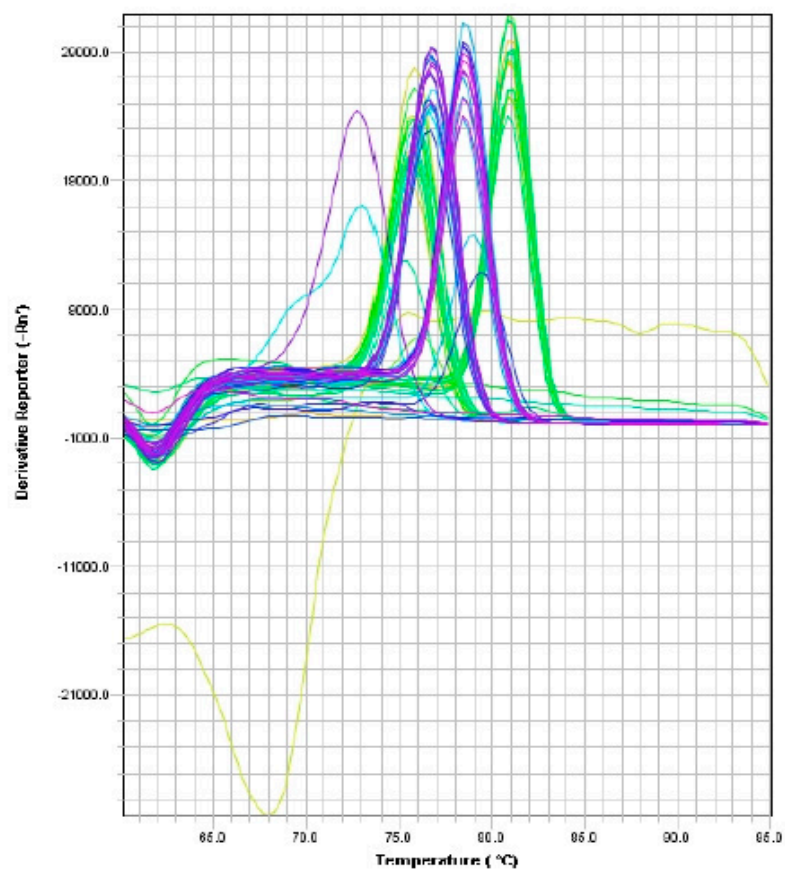

D

Figure 9. Melting curves observed for qPCR analysis of the relative expression of PAL, POD, SOD, WRKYa, PAL1, DEF-1, CAT-2, WRKY40, HSFC1, LOX2, and NPR1 genes normalized to UBI3 after different treatments: mock, RS (R. solanacearum), KA9 + RS (Bacillus subtilis + R. solanacearum), PDS1 + RS (Pseudomonas fluorescens + R. solanacearum), KA9 + PDS1 + RS (Bacillus subtilis + Pseudomonas fluoresecens $+R$. solanacearum), and BABA (chemical control). Melting curve (A) and amplification plot (B) observed for qPCR analysis of relative expression of normalized Ubi3 gene in chili. (C) Genes yielding a single melting curve. (D) Genes shown multiple peaks (marked by red arrows) were excluded from the analysis. 



Figure 10. (a) Principal component analysis of defense-related genes in terms of expression levels following treatment with biocontrol agents in leaves and roots of chili against $R$. solanacearum in glasshouse conditions (b) Elicitation of defense-related gene expression (PAL, POD, SOD, WRKYa, PAL1, DEF-1, CAT-2, WRKY40, HSFC1, LOX2, and NPR1) by P. fluorescens PDS1 and B. subtilis KA9 in chili against $R$. solanacearum pathogen challenge in roots and leaves, $48 \mathrm{~h}$ after inoculation in glasshouse conditions.

In leaves, the maximum relative expression of PAL gene was recorded at $48 \mathrm{~h}$ after treatment with BABA (4.28-fold), followed by KA9 + PDS1 + RS (3.25-fold), KA9 + RS (2.75-fold), PDS1 + RS (2.59-fold), and RS (2.04-fold) as compared to UBI3. A significant variation was observed in the dual KA9 + PDS1 + RS treatment compared to the mock inoculated control, as well as individual rhizobacterial treatments. Upregulation of defensive gene PAL in leaves was found in all treatments as compared to UBI3 (Supplementary Table S10). 
The relative expression of PAL gene in root samples was greater than in leaf samples after all treatments.

\subsubsection{POD (Peroxidase) Gene}

In the susceptible cv. Pusa Jwala, the mock treatment was used to calibrate the expression of defense-related genes. The highest relative expression of POD gene was recorded at $48 \mathrm{~h}$ after treatment with BABA (3.5-fold), followed by KA9 + PDS1 + RS (3.22-fold), PDS1 + RS (2.6-fold), KA9 + RS (2.29-fold), and RS (2.26-fold). The relative expression observed in response to RS and KA9 + RS treatments was not significantly different during the study. However, the dual rhizobacterial treatment KA9 + PDS1 + RS was found to vary significantly from individual rhizobacterial inoculated treatments. Upregulation of defensive gene POD was found in all treatments as compared to UBI3 in the plant roots (Figure 10a,b) (Supplementary Table S9). In leaves, a similar pattern of POD gene expression was recorded. The highest relative expression of POD in leaf samples of cv. Pusa Jwala was recorded at $48 \mathrm{~h}$ after treatment with BABA (3.15-fold), followed by KA9 + PDS1 + RS (2.39-fold), PDS1 + RS (2.10-fold), KA9 + RS (1.99-fold), and RS (1.96-fold). A significant variation was observed in the relative expression after dual rhizobacterial treatment (KA9 + PDS1 + RS) compared to individual rhizobacterial treatments, but no significant variation in relative expression was observed between PDS1 + RS and KA9 + RS treatments. Upregulation of defensive gene POD in leaves was found in all treatments as compared to UBI3 (Supplementary Table S10). The relative expression of POD gene in root samples of cv. Pusa Jwala was greater than in leaf samples after all treatments in glasshouse conditions.

\subsubsection{SOD (Superoxide Dismutase) Gene}

The highest relative expression of SOD gene was recorded at $48 \mathrm{~h}$ in roots of $\mathrm{cv}$. Pusa Jwala after treatment with BABA (3.68-fold), followed by KA9 + PDS1 + RS (3.57-fold), KA9 + RS (2.46-fold), PDS1 + RS (2.12-fold), and RS (1.03-fold). The relative expression observed in response to PDS1 + RS and KA9 + RS treatments was not significantly different; however, there was a significant variation between dual rhizobacterial treatment $(\mathrm{KA} 9+\mathrm{PDS} 1+\mathrm{RS})$ and individual rhizobacterial treatments after $48 \mathrm{~h}$. Upregulation of defensive gene SOD was found in all treatments compared to UBI3. In leaves of cv. Pusa Jwala, the highest relative expression of SOD was recorded at $48 \mathrm{~h}$ after treatment with BABA (3.60-fold), followed by KA9 + PDS1 + RS (2.70-fold), PDS1 + RS (1.62-fold), KA9 + RS (1.00-fold), and RS (2.03-fold). The relative expression observed in the dual rhizobacterial inoculation treatment (KA9 + PDS1 + RS) was significantly different from that in individual rhizobacterial treatments. The relative expression observed in response to control and KA9 + RS treatments was not significantly different after $48 \mathrm{~h}$ inoculation of rhizobacteria. Upregulation of defensive gene SOD in leaves was found in all treatments compared to UBI3 (Figure 10a,b) (Supplementary Tables S9 and S10). The relative expression of SOD gene in root samples of $\mathrm{cv}$. Pusa Jwala was greater than in leaf samples after all treatments.

\subsubsection{WRKYa Gene}

The highest relative expression of WRKYa gene in roots was recorded at $48 \mathrm{~h}$ after treatment with BABA (2.66-fold), followed by KA9 + PDS1 + RS (1.43-fold), KA9 + RS (1.36-fold), PDS1 + RS (0.82-fold), and RS (0.64-fold). No significant variation in the relative expression of WRKYa gene was recorded in roots of cv. Pusa Jwala between dual rhizobacterial treatment (KA9 + PDS1 + RS) and individual rhizobacterial treatments. Upregulation of defensive gene WRKYa was found in all treatments compared to UBI3. In leaves, the highest relative expression of WRKYa was recorded at $48 \mathrm{~h}$ after treatment with BABA (1.90-fold), followed by KA9 + PDS1 + RS (1.20-fold), PDS1 + RS (0.82-fold), KA9 + RS ( 0.80 -fold), and RS (0.32-fold). A significant variation in relative expression between dual rhizobacterial treatment (KA9 + PDS1 + RS) and individual rhizobacterial treatments was recorded in leaf samples after $48 \mathrm{~h}$ of treatment. However, the relative expression observed in response to KA9 + RS and PDS 1 + RS treatments was not significantly different. Up- 
regulation of defensive gene WRKYa in leaves was found in all treatments compared to UBI3 (Figure 10 WRKY-Leaf). The relative expression of WRKYa gene in the roots of cv. Pusa Jwala was greater than leaf samples after all treatments (Figure 10a,b) (Supplementary Tables S9 and S10).

\subsubsection{PAL1 (Phenyl Ammonia Lyase) Gene}

The highest relative expression of PAL1 gene was recorded in the roots of $\mathrm{cv}$. Pusa Jwala at $48 \mathrm{~h}$ after treatment with BABA (5.04-fold), followed by PDS1 + RS (1.58-fold), RS (1.51-fold), KA9 + PDS1 + RS (1.17-fold), and KA9 + RS (0.99-fold). The relative expression observed after PDS1 + RS treatment was significantly different from the control and other treatments. Upregulation of defensive gene PAL1 was found in all treatments compared to UBI3. In leaves, a similar pattern of PAL1 gene expression was recorded. The highest relative expression of PAL1 was recorded at $48 \mathrm{~h}$ after treatment with BABA (2.00-fold), followed by PDS1 + RS (1.90-fold), KA9 + PDS1 + RS (1.57-fold), KA9 + RS (1.50-fold), and RS (0.86-fold). The relative expression observed after the PDS1 + RS treatment differed significantly from the mock control and other treatments. Upregulation of defensive gene PAL1 was found in all treatments except for the uninoculated mock, which presented a downregulation compared to UBI3. Rhizobacteria induced PAL1 gene expression more in leaf tissue than in root tissue, whereas chemical BABA treatment induced PAL1 gene expression more in root tissue than in leaf tissue (Figure 10a,b) (Supplementary Tables S9 and S10).

\subsubsection{DEF1 (Defensive) Gene}

The highest relative expression of DEF1 gene was recorded at $48 \mathrm{~h}$ after treatment with BABA (4.03-fold), followed by KA9 + PDS1 + RS (2.11-fold), KA9 + RS (1.11-fold), PDS1 + RS (0.48-fold), and RS (1.62-fold). The combined KA9 + PDS1 + RS treatment showed a significant variation in relative expression compared to other rhizobacterial treatments. Upregulation of defensive gene DEF1 was found in all treatments compared to UBI3. In leaves, the highest relative expression of DEF1 was recorded in cv. Pusa Jwala at $48 \mathrm{~h}$ after treatment with BABA (3.00-fold), followed by KA9 + PDS1 + RS (1.61-fold), KA9 + RS (1.70-fold), PDS1 + RS (0.90-fold), and RS (1.20-fold). The dual rhizobacterial treatment (KA9 + PDS1 + RS) differed significantly in terms of the relative expression of DEF1 from individual rhizobacterial treatments. Upregulation of defensive gene DEF1 in leaves was recorded in all cases, except for the uninoculated mock which exhibited a downregulation compared to UBI3. It was also noted that, after RS, KA9 + PDS1 + RS, and BABA treatments, DEF1 gene was expressed more in root tissue than in leaf tissue, whereas the opposite was found for KA9 + RS and PDS1 + RS treatments (Figure 10a,b) (Supplementary Tables S9 and S10).

\subsubsection{CAT2 (Catalase 2) Gene}

The highest relative expression of CAT2 gene was recorded at $48 \mathrm{~h}$ in root tissue of $\mathrm{cv}$. Pusa Jwala after treatment with BABA (3.75-fold), followed by KA9 + PDS1 + RS (0.91-fold) and KA9 + RS (2.6-fold). There was no significant variation between PDS1 + RS (-0.34-fold) and RS (-0.34-fold) treatments; however, both cases exhibited downregulation of CAT2. The relative expression observed in the dual rhizobacterial inoculation (KA9 + PDS1 + RS) differed significantly from individual rhizobacterial treatments. Upregulation of defensive gene CAT2 was found after treatment with BABA, PDS1 + KA9 + RS, and KA9 + RS, whereas downregulation was observed for PDS1 + RS and RS, compared to UBI3. In leaves, the highest relative expression of CAT2 gene was recorded at $48 \mathrm{~h}$ after treatment with BABA (2.70-fold), followed by KA9 + PDS1 + RS (1.91-fold), PDS1 + RS (1.34-fold), KA9 + RS (1.20-fold), and RS (0.60-fold). The relative expression of CAT2 gene observed after dual rhizobacterial treatment with KA9 + PDS1 + RS differed significantly from individual rhizobacterial treatments. Upregulation of defensive gene CAT2 was recorded in leaves, except for the uninoculated mock which exhibited downregulation compared to UBI3. KA9 + RS, KA9 + PDS1 + RS, and BABA treatments induced more CAT2 activity 
in the roots of cv. Pusa Jwala, whereas the opposite was found for RS and PDS1 + RS treatments (Figure 10a,b) (Supplementary Tables S9 and S10).

\subsubsection{WRKY40 Gene}

The highest relative expression of WRKY40 gene was recorded at $48 \mathrm{~h}$ in root tissue of cv. Pusa Jwala after treatment with BABA (1.01-fold), followed by KA9 + PDS1 + RS (0.91-fold), and PDS1 + RS (0.24-fold). The relative expression observed in the dual rhizobacterial inoculation (KA9 + PDS1 + RS) differed significantly from individual rhizobacterial treatments. Upregulation of defensive gene WRKY40 was observed after BABA, PDS1 + KA9 + RS, and PDS1 + RS treatment, whereas downregulation of WRKY40 was observed after KA9 + RS and RS treatment, compared to UBI3. BABA treatment differed significantly from rhizobacterial treatments. In leaves, the highest relative expression of WRKY40 was recorded at $48 \mathrm{~h}$ after treatment with BABA (1.50-fold), followed by PDS1 + RS (1.40-fold), KA9 + RS (1.30-fold), KA9 + PDS1 + RS (0.90-fold), and RS (-0.65-fold). The relative expression observed after PDS1 + RS (1.40-fold) and KA9 + RS (1.30-fold) treatments was not significantly different, unlike individual rhizobacterial treatments compared to the dual inoculation (KA9 + PDS1 + RS). Upregulation of defensive gene WRKY40 was recorded in leaves, except for the pathogenic treatment of $R$. solanacearum, which exhibited downregulation compared to UBI3. The WRKY40 gene was relatively expressed more in leaf tissue as compared to root tissue after all treatments (Figure 10a,b) (Supplementary Tables S9 and S10).

\subsubsection{HFSC1 Gene}

The highest relative expression of HFSC1 gene was recorded in root tissues of cv. Pusa Jwala after treatment with RS (1.08-fold), followed by KA9 + PDS1 + RS (0.90-fold) and BABA (0.87-fold), KA9 + RS (0.24-fold), and PDS1 + RS (-0.25-fold). Plants treated with RS only showed a significantly higher relative expression of HFSC1 gene in root tissues than in rhizobacterial treatments. Upregulation of defensive gene HFSC1 was found in treatments BABA, PDS1 + KA9 + RS, and KA9 + RS, whereas downregulation was observed in treatment PDS1 + RS. In leaves, the highest relative expression of HFSC1 was recorded after treatment with KA9 + PDS1 + RS (1.5-fold), followed by KA9 + RS (0.90-fold) and RS (0.90-fold), BABA (0.87-fold), and PDS1 + RS (0.80-fold). The dual culture of rhizobacteria KA9 + PDS1 + RS exhibited a higher relative expression of HFSC1 gene than single rhizobacterial treatments. Upregulation of defensive gene HFSC1 in leaf tissue was observed in all samples compared to UBI3 (Figure 10a,b) (Supplementary Tables S9 and S10). With the exception of RS treatment, there was a higher relative expression of HFSC1 gene in leaf tissue than in root tissue.

\subsubsection{LOX2 (Lipoxygenase 2) Gene}

The highest relative expression of LOX2 gene was recorded in root tissue of cv. Pusa Jwala at 48 h after treatment with KA9 + PDS1 + RS (0.84-fold), followed by PDS1 + RS (0.04-fold), CC (-0.63-fold), KA9 + RS (-0.93-fold), and RS (-0.98-fold). There was no significant difference in expression of LOX2 between uninoculated mock and PDS + RS treatments. The relative expression observed in the dual microbial inoculation was found significantly higher compared to the mock control and other treatments. Upregulation of defensive gene LOX2 was found after PDS1 + KA9 + RS and PDS1 + RS treatments, whereas downregulation was observed after KA9 + RS, RS, and BABA treatments, compared to UBI3. In leaves, the highest relative expression of LOX2 was recorded after treatment with RS (1.98-fold), followed by KA9 + PDS1 + RS (1.84-fold) KA9 + RS (1.07-fold), and PDS1 + RS (1.04). The lowest relative expression of LOX2 gene was recorded after treatment with BABA. Dual rhizobacterial treatment exhibited a significantly higher relative expression of LOX2 gene compared to single rhizobacterial treatments. Upregulation of defensive gene LOX2 in leaves was observed in all samples except for the chemical control, compared to UBI3. Except for the chemical treatment, all treatments induced greater LOX1 gene 
expression in leaf tissue than in root tissue after $48 \mathrm{~h}$ of inoculation in glasshouse conditions (Figure 10a,b) (Supplementary Tables S9 and S10).

\subsubsection{NPR1 (Nonexpressor of Pathogen-Related) Gene}

The highest relative expression of NPR1 gene was recorded at $48 \mathrm{~h}$ in the tissue of cv. Pusa Jwala after treatment with BABA (3.13-fold), followed by KA9 + PDS1 + RS (0.96-fold), KA9 + RS (0.94-fold), PDS1 + RS (0.82-fold), and RS (0.52-fold). The relative expressional of NPR1 gene in plants treated with KA9 + PDS1 + RS and KA9 + RS did not differ significantly, whereas treatment with the chemical control BABA differed significantly from the mock control and other treatments. Upregulation of defensive gene NPR1 was found in all treatments compared to UBI3. In leaves, the highest relative expression of NPR1 gene was recorded at $48 \mathrm{~h}$ after treatment with BABA (2.15-fold), followed by KA9 + RS (0.67-fold), PDS1 + RS (-0.22-fold), KA9 + PDS1 + RS (-0.74-fold), and RS (-0.93-fold). The relative expression of NPR1 gene observed in BABA-treated plants significantly differed from other treatments. Upregulation of defensive gene NPR1 in leaves was found in BABA and KA9 + RS treatments, whereas downregulation occurred in KA9 + PDS1+ RS (-0.22-fold) and PDS1 + RS (-0.22-fold) treatments, compared to UBI3. The root tissue of cv. Pusa Jwala showed a greater relative expression of NPR2 gene at $48 \mathrm{~h}$ than the leaf tissue after all treatments (Figure 10a,b) (Supplementary Tables S9 and S10).

\subsection{Overall Relative Expression of Defensive Genes in Leaves and Roots of Chili}

In this study, the relative expression of 11 defense-related genes was studied in chili cv. Pusa Jwala to determine ISR; in particular, PAL, PAL1, WRKYa, DEF1, CAT2, and WRKY40 genes led to an induction in the plants as compared to the control, with 1-5 log fold changes following exogenous application of BABA ( $\beta$-aminobutyric acid). It was observed that most genes showed an enhancement of their transcription levels ranging from $0.5-4.0 \log$ fold change. Maximum expression modulation was observed for PAL gene, i.e., $~ 4.0$ log fold increase in both root and leaf tissues. POD, SOD, and CAT2 showed a 3.0 log fold increase after B. subtilis KA9 and P. fluorescens PDS1 treatments. In contrast, NPR1 does not show an increase after treatment with individual rhizobacteria, but showed a $1.5 \mathrm{log}$ fold increase after all combined treatments except for Pseudomonas and Ralstonia (Figure 11).
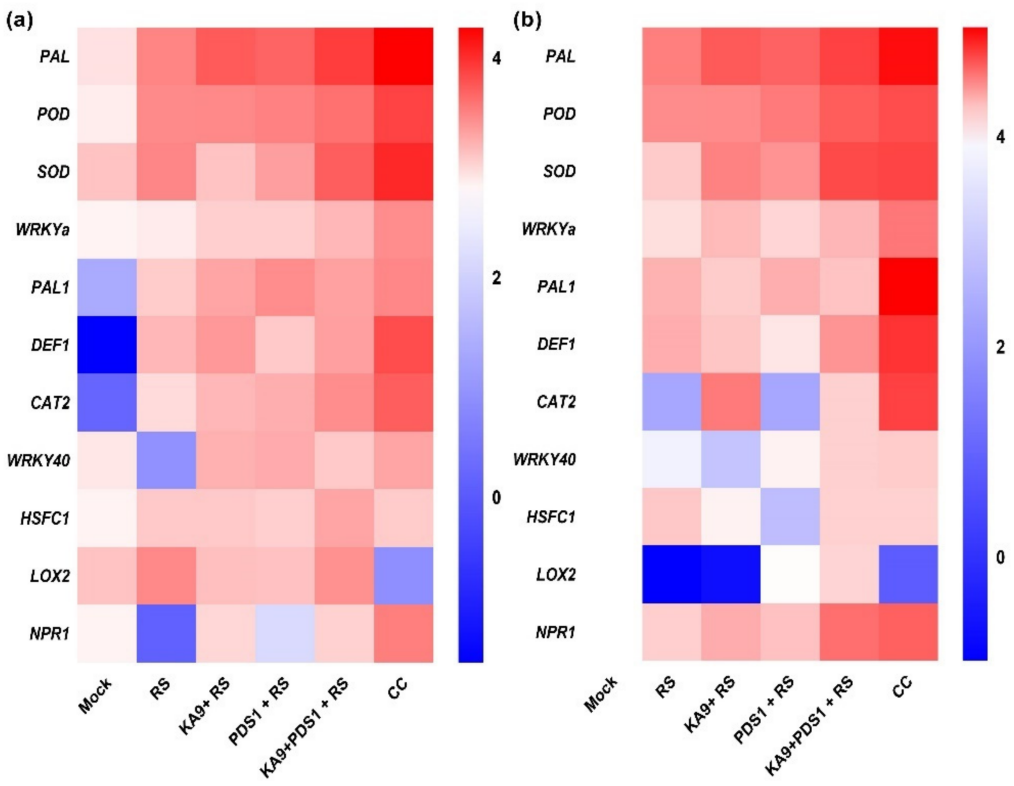

Figure 11. Comparative gene expression (PAL, POD, SOD, WRKYa, PAL1, DEF-1, CAT-2, WRKY40, HSFC1, LOX2, and NPR1 genes) after treatment with P. fluorescens PDS1 and B. Subtilis KA9 in chili against $R$. solanacearum pathogen challenge in (a) leaves and (b) roots at $48 \mathrm{~h}$ after inoculation in glasshouse conditions. 
3.9. Biocontrol of Bacterial Wilt Disease and Plant Growth Attributes after Different Treatments with Volatile Compound-Producing Rhizobacteria

In the present study, two rhizobacteria B. subtilis KA9 and P. fluorescens PDS1 were selected on the basis of their antagonistic and plant-growth promoting abilities under in vitro conditions. In glasshouse conditions at the National Phytotron Facility, IARI, New Delhi, these rhizobacteria isolates (KA9 and PDS1) were investigated for their bioefficacy in managing bacterial wilt disease and growth promotion activities in chili cV. Pusa Jwala (susceptible cv.). Individual and dual inoculation of isolates PDS1 and KA9 significantly reduced the bacterial wilt incidence in chili and enhanced the growth of the plants. Minimum disease intensity $(21.80 \%)$ was recorded in BABA-treated plants followed by treatment with KA9 + PDS1 + RS (22.40\%), KA9 + RS (26.50), and PDS1 + RS (26.80) after 40 days of pathogen inoculation.

Maximum biocontrol efficacy $(72.05 \%)$ was recorded in BABA-treated plants followed by treatment with KA9 + PDS1 + RS (71.28\%), KA9 + RS (66.02\%), and PDS1 + RS (65.64\%). The bacterial wilt disease symptoms were initiated only in $R$. solanacearum-infected plants after 16 days of inoculation, whereas in rhizobacteria-treated plants, appearance of wilt disease was delayed by 10-14 days. Moreover, a significant variation in reduction in wilt disease in chili was recorded among these isolates in glasshouse conditions $(p>0.05)$ (Table 5). After 40 days of treatment, plant growth promoters were documented for their effects on growth promoting efficacy, plant length, root and shoot dry weight. The maximum shoot length $(21.70 \mathrm{~cm})$ was recorded after KA9 + PDS1 + RS treatment, followed by BABA $(20.8 \mathrm{~cm}), \mathrm{KA}-9$ + RS $(19.80 \mathrm{~cm})$, PDS1 + RS $(18.60 \mathrm{~cm})$, and mock $(16.6 \mathrm{~cm})$, while the minimum shoot length was recorded after RS treatment $(10.30 \mathrm{~cm})$. The maximum root length (12.22) cm was recorded after KA9 + PDS1 + RS treatment, followed by KA-9 + RS $(12.06 \mathrm{~cm})$, PDS1 + RS $(11.82 \mathrm{~cm})$, BABA $(11.32 \mathrm{~cm})$, and mock $(9.61 \mathrm{~cm})$, and the minimum root length was recorded after treatment with RS $(7.82 \mathrm{~cm})$. Clustvis 2.0 online software was used to perform principal component analysis. Two main components PC1 and PC2 were observed to explain $99.80 \%$ of the variance. Growth parameter variables were substantially linked with PC1 and PC2 and were located in the same eclipse (excluding dry weight) at the 95\% significance level. The results concluded that PDS1, KA9, and $\beta$-aminobutyric acid treatments, comprising eclipse I and eclipse II, showed significant positive responses to various growth parameters (Figure 12a).

Table 5. Evaluation of potential of antagonistic rhizobacteria in terms of growth promotion of chili 40 days after inoculation in glasshouse conditions.

\begin{tabular}{|c|c|c|c|c|c|c|c|c|c|c|}
\hline $\begin{array}{c}\text { Strains Treat- } \\
\text { ment/Growth Trait }\end{array}$ & $\begin{array}{l}\text { Wilt Disease } \\
\text { Incidence (\%) }\end{array}$ & $\begin{array}{l}\text { Biocontrol } \\
\text { Efficacy (\%) }\end{array}$ & $\begin{array}{c}\text { Shoot } \\
\text { Length }(\mathrm{cm})\end{array}$ & $\begin{array}{c}\text { Shoot } \\
\text { Fresh } \\
\text { Weight (g) }\end{array}$ & $\begin{array}{l}\text { Shoot Dry } \\
\text { Weight (g) }\end{array}$ & $\begin{array}{l}\text { GPE } \\
(\%)\end{array}$ & $\begin{array}{c}\text { Root } \\
\text { Length }(\mathrm{cm})\end{array}$ & $\begin{array}{l}\text { Root Fresh } \\
\text { Weight (g) }\end{array}$ & $\begin{array}{l}\text { Root Dry } \\
\text { Weight (g) }\end{array}$ & $\begin{array}{l}\text { GPE } \\
(\%)\end{array}$ \\
\hline RS & $78^{a}$ & - & $10.3^{f}$ & $7.2^{f}$ & $0.68^{\mathrm{e}}$ & - & $7.82^{f}$ & $0.88^{f}$ & $0.18^{\mathrm{e}}$ & - \\
\hline MOCK & $0^{\mathrm{e}}$ & - & $16.6^{\mathrm{e}}$ & $8.5^{\mathrm{e}}$ & $0.98^{\mathrm{d}}$ & 44.11 & $9.61^{\mathrm{e}}$ & $1.76^{\mathrm{e}}$ & $0.28^{\mathrm{d}}$ & 55.56 \\
\hline KA9 + RS & $26.50^{b}$ & $66.02^{b}$ & $19.8^{\mathrm{c}}$ & $9.8^{c}$ & $1.18^{\mathrm{b}}$ & 73.35 & $12.06^{\mathrm{b}}$ & $1.87^{\mathrm{c}}$ & $0.31^{b}$ & 72.22 \\
\hline PDS1 + RS & $26.80^{b}$ & $65.64^{c}$ & $18.6^{\mathrm{d}}$ & $8.7^{\mathrm{d}}$ & $1.14^{\mathrm{c}}$ & 67.64 & $11.82^{\mathrm{c}}$ & $1.79^{\mathrm{d}}$ & $0.30^{c}$ & 66.67 \\
\hline KA9 + PDS1 + RS & $22.40^{c}$ & $71.28^{\mathrm{a}}$ & $21.7^{\mathrm{a}}$ & $11.5^{\mathrm{a}}$ & $1.23^{\mathrm{a}}$ & 80.88 & $12.22^{\mathrm{a}}$ & $1.89^{\mathrm{b}}$ & $0.32^{a}$ & 77.78 \\
\hline BABA & $21.80^{\mathrm{d}}$ & $72.05^{a}$ & $20.8^{b}$ & $10.9^{b}$ & $1.14^{\mathrm{c}}$ & 69.11 & $11.32^{\mathrm{d}}$ & $1.96^{\mathrm{a}}$ & $0.32^{\mathrm{a}}$ & 77.00 \\
\hline
\end{tabular}

Values given in column are the average of three replications. Values with different alphabetical (a-f) superscripts within a column are significantly different as determined by LSD test $(\alpha=0.05)$.

$\mathrm{KA} 9+$ PDS1 + RS treatment resulted in the highest shoot dry weight of $1.23 \mathrm{~g}$, followed by KA-9 + RS (1.18 g), PDS1 + RS (1.14 g), BABA (1.14 g), mock (0.98 g), and RS (0.68 g). The growth promotion efficiency (GPE) of shoots on a dry weight basis was calculated in comparison to the RS treatment, revealing the maximum value for KA9 + PDS1 + RS (80.87\%) followed by KA-9 + RS (73.35\%), BABA (69.11\%), PDS1 + RS (67.64\%), and mock $(44.11 \%)$ (Table 5$)$. The maximum root dry weight $(0.32 \mathrm{~g})$ was recorded after KA9 + PDS1 + RS and BABA treatments, followed by KA-9 + RS (0.31 g), PDS1 + RS $(0.30 \mathrm{~g})$, mock $(0.28 \mathrm{~g})$, and RS $(0.18 \mathrm{~g})$. The growth promotion efficiency of roots on a dry weight basis was calculated in comparison to the RS treatment, revealing the maximum 
value for KA9 + PDS1 + RS (77.76\%), followed by BABA $(77.00 \%)$, KA-9 + RS (72.22\%), PDS1 + RS (66.67\%), and mock (55.56\%) (Figure 12b).


Figure 12. (a) Principal component analysis showing correlation and significance of growth metrics impacted by rhizobacterial strains in chili. (b) Graph showing biocontrol efficacy (\%) following the various treatments with rhizobacteria against bacterial wilt disease.

\section{Discussion}

The effects of volatile compounds (VOCs) produced by five rhizobacterial strains, PDS-1, UK-2, UK-4, BDS-1, and KA-9, on the growth and virulence features of the chili wilt pathogen $R$. solanacearum were investigated in this study. The VOCs produced by these isolates significantly inhibited the growth of $R$. solanacearum under in vitro conditions. The highest inhibition was recorded by strain PDS-1 (P. fluorescens) (72.24\%) compared to the control. The results were concordant with the findings of Raza et al. [8], who reported that volatile organic compounds produced by $P$. fluorescens WR-1 restricted the growth and virulence traits of $R$. solanacearum. The effect of VOCs produced by different biocontrol strains on $R$. solanacearum has not been recorded; nevertheless, VOCs produced by the fungal pathogen Aspergillus flavus resulted in a fourfold decrease in R. solanacearum growth [34]. Other investigations found that $P$. fluorescens strains produced antimicrobial VOCs and suppressed the growth of the phytopathogen Botrytis cinerea [35]. P. fluorescens B-4117 produced VOCs that inhibited the growth of Agrobacterium tumefaciens and Agrobacterium vitis [36]. In this study, other strains belonging to the Bacillus genera showed significant inhibition activity against $R$. solanacearum, confirming the findings of Tahir et al. [10], who reported the effect of Bacillus volatile compounds against $R$. solanacearum in tobacco plant. Similar findings were also reported by Raza et al. [12], who showed the response of $R$. solanacearum 
to volatile organic compounds produced by biocontrol strain B. amyloliquefaciens SQR-9. The inhibitory activity of biocontrol agents in our study was due to presence of 2-ethyl3,6-dimethyl pyrazine, 3-hydroxy-2-butanone (acetoin), benzothiazole, cycloheptasiloxane, and 2-methyl pyrazine compounds, in line with the results of Goa et al. [37], who identified pyrazine and benzothiazole as the significant inhibitory VOCs generated by B. subtilis CF-3.

\subsection{Induction of Systemic Resistance by Rhizobacteria}

This repeatedly showed that biocontrol agents such as B. subtilis KA9 and P. fluorescens PDS1 trigger a cascade of defense enzymes against $R$. solanacearum. To counter soil-borne diseases, rhizobacteria can induce systemic resistance in a range of plants, according to several studies. Plant growth-promoting bacteria (PGPB) use ISR to prime the entire plant body for disease resistance. Activation of latent defensive responses occurs not just at the induction site, but also systemically across plant tissues [38]. Plant defense enzymes such as polyphenol oxidase phenyl ammonia lyase and peroxidase can be activated by secondary metabolites generated by Bacillus species that induce systemic resistance [39]. PPO and $\mathrm{PO}$ are oxidative enzymes that can accelerate the synthesis of lignin and other oxidative phenols. The cell structure's protective mechanism is changed to activate pathogen defense barriers [40].

According to the results of this study, in chili cv. Pusa Jwala, the combined treatment of $B$. subtilis KA9 and $P$. fluorescens PDS1 against $R$. solanacearum resulted in higher polyphenol oxidase, peroxidase, superoxide dismutase, and phenyl ammonia lyase activity, which increased up to 48 hapi, before gradually decreasing in all treatments. There was no increase in enzyme activity in the untreated control group. This result is supported by Jayapala et al. [39], who found that biopriming chili seeds with Bacillus sp. boosted defense-related enzymes such as PAL, peroxidase, and polyphenol oxidase at 48 hapi against Colletotrichum capsici. Chunyu et al. [41] found that treating tomato plants with B. amyloliquefaciens SQRT3 and R. solanacearum boosted PO and PPO activities; their findings were similar to the results of the current investigation. Pretreating tomato seedlings with P. fluorescens conferred systemic resistance against Fusarium oxysporum f.sp. lycopersici, according to Ramamoorthy et al. [42]. According to Kashyap et al. [33], biopriming chili seeds with rhizobacteria improved ISR against $R$. solanacearum by increasing peroxidase and phenyl ammonia lyase activities. According to Ho et al. [43], the jasmonic acid signaling pathway is important in the tomato's defense mechanism against $R$. solanacearum. The findings of this study are backed up by observations of tomato plants treated with B. subtilis against the pathogen Erwinia carotovora subsp. carotovora, which boosted the activities of phenyl ammonia lyase and superoxide dismutase in seedlings [44]. Increased SOD causes more $\mathrm{H}_{2} \mathrm{O}_{2}$ to be deposited, which is required for plant disease resistance [45]. The majority of these data are in line with recent discoveries showing an increase in defense enzymes such PAL, PPO, POD, and SOD, which are involved in the prevention of plant disease [46]. Our findings matched those of Vanitha et al [47], who found that pretreatment with $P$. fluorescens enhanced the defense related enzyme activities like PAL, $\mathrm{PO}$, Lipoxygenase $\mathrm{PPO}$ in tomato seedlings post inoculated with $R$. solanacearum.

\subsection{Production of Volatile Compounds by Rhizobacteria}

Microorganism-produced volatiles have been found to play an essential environmental role in the induction of systemic resistance to biotic elements, plant growth promotion, and bacterial pathogen suppression through beneficial interactions between PGPRs and plants [15]. Studies on bacterial volatile compounds (VOCs) and their effects on plant development and systemic resistance focused mostly on the interaction between PGPRproduced VOCs and plants [13]. The tripartite interaction involving microorganisms (PGPR strains B. subtilis KA9 and P. fluorescens PDS-1), a plant pathogenic bacterium (R. solanacearum), and the host chili plant was demonstrated in this study. Beneficial and pathogenic bacteria coexist in soil, and their efficacy as a PGPR or pathogen is influenced by the rhizosphere population, soil nutrition, and environmental variables. In soil, several 
relationships influence biological activity. In this work, the interaction effects of volatile compounds (VOCs) produced by both PGPR strains on the elicitation of defense reactions in the host chili were investigated. A significant difference was observed in all treatments of rhizobacteria with respect to defensive enzyme elicitation (PAL, PPO, PO, and SOD) when chili seedlings were exposed to volatile compounds produced by these rhizobacterial combinations in all experimental systems. During exposure to the pathogenic bacteria $R$. solanacearum VOCs, no huge variations were seen. In earlier studies, the inverted plate technique was utilized to determine whether VOCs can promote plant growth or induce systemic resistance. Generally, artificial growth medium is utilized in an inverted plate setup for plant growth studies; however, VOCs can only reach the leaves due to their solid or semisolid nature, leaving the roots unharmed. Another factor to consider is that, when pathogens are inoculated to test for induced systemic resistance, the pathogen grows on the growth medium surface and contaminates the inverted plate setup. To avoid this issue, we modified the method in this study by utilizing a half-inverted bottle system, in which soil mixed with vermiculite was employed as a plant development medium. VOCs could reach seedling roots through small pores in the soil-vermiculite combination in this transparent system. PGPR colonized soil organically, and the VOCs it produced could interact with the plant roots rather than leaves in natural settings. To investigate the growth-stimulating action of rhizobacteria VOCs in soil exposed to roots, the experiment was relocated from in vitro conditions to pots in a growth chamber with an $\mathrm{RH}$ of $80 \%$ and a temperature of $28{ }^{\circ} \mathrm{C}$. The findings demonstrated that rhizobacterial VOCs encouraged development under soil conditions, and the results are supported by an earlier study by Park et al. [16]. Volatile organic compounds produced by microorganisms, caused many physiological changes related to defence enzymes, growth hormones, and photosynthesis [22]. Following exposure to rhizobacterial-VOCs, the results revealed a considerable increase in defense enzyme activity, implying that rhizobacterial VOCs can activate plant defensive mechanisms. Metabolites and defense-related enzymes enhance in concentration as a consequence of a buildup of resistance, such as PAL, according to molecular research. In addition to the generation of phenols, which operate in chemical defense, the enzyme PAL plays an important role in the regulation of lignin accumulation and the formation of defensive structures [48,49]. PPO catalyzes the oxygen-dependent oxidation of phenols, while PAL is implicated in the plant salicylic acid-mediated defense against pathogens. Both PPO and PAL are involved in the pathogenic microbe resistance process [50]. In response to pathogen attacks, plants exposed to VOCs increase their PPO and PAL levels. These findings corroborate recent research indicating an increase in the activity of PAL, PPO, and PO enzymes in Bacillus-treated tomato plants, which led to a decrease in wilt disease [51].

\subsection{Expression of Rhizobacteria-Mediated Defense-Related Genes against R. solanacearum in Chili}

Defense-related genes such as lipoxygenase (LOX), peroxidase (POD), phenyl ammonia lyase (PAL), superoxide dismutase (SOD), catalase (CAT), and defensin gene (DEF) were chosen to study their relative expression in the root and leaf tissue of chili induced by rhizobacteria and a chemical known to be directly associated with inducing systemic resistance through expression at both transcript and protein levels [52-58]. The WRKY (WRKYa, WRKY40) and HSF (HSFC) genes are transcription factors that act as activators or repressors of triggered immunity in the plant [59-63]. These genes are also involved in modulating gene expression during pathogen-associated molecular pattern-triggered immunity, as well as effector-triggered immunity. Furthermore, NPR1 (a nonexpressor of pathogenesis-related gene) contributes to the overall plant health when the immune response of the plant is increased [64-66]. Hence, qPCR was performed to study the relative expression of these genes in comparison with ubiquitin following different treatments with rhizobacteria and $R$. solanacearum in chili to understand the biology of systemic resistance induction. 


\subsubsection{PAL gene}

The relative expression of PAL gene in response to different treatments (RS (R. solanacearum), $\mathrm{KA} 9+\mathrm{RS}$ (B. subtilis KA9+ R. solanacearum), PDS1 + RS (P. fluorescens PDS1 + R. solanacearum), KA9 + PDS1 + RS (B. subtilis KA9 + P. fluorescens PDS1 + R. solanacearum), BABA (chemical control), and mock inoculated treatments) on the Pusa Jwala cultivar of chili was studied. The BABA-treated leaf and root showed the highest relative expression of PAL gene at $48 \mathrm{~h}$, which indicates that the priming of ISR maintains plant fitness when pathogens attack. In addition to chemical-induced priming of ISR, the priming effects can be elicited by rhizobacteria $[67,68]$. In this study, the relative expression of PAL gene was observed in response to different rhizobacteria treatments. PDS1 + RS and KA9 + RS treatments did not differ significantly, whereas the dual rhizobacterial treatment (KA9 + PDS1 + RS) was significantly better than the control and individual rhizobacterial treatments. The PAL gene was upregulated in all treatments compared to UBI3. These results agree with those reported by Chandrashekran and Chun [44], who tested the efficiency of B. subtilis CBR05 as a biocontrol agent for soft rot disease (Erwinia carotovora subsp. carotovora) in tomato and found that the PAL gene exhibited the most significant upregulation in the transcript profile. The general conclusion was that increases in PAL activity were caused by the increased expression of PAL gene. Previous studies [69-72] also reported that the PAL activity in hosts induced by microbial antagonists was linked to their biocontrol effects. When peach fruit was challenged with the pathogen Colletotrichum acutatum, Wang et al. [73] found that B. cereus AR156 treatment stimulated the expression of three defense-related genes, resulting in higher ISR and reduced anthracnose rot.

In this study, a similar pattern of relative expression of PAL gene was found in leaf samples, with BABA treatment showing the maximum fold expression, followed by the dual rhizobacterial inoculation (KA9 + PDS1 + RS). Upregulation of defensive gene PAL in leaves was found in all treatments compared to UBI3. The relative expression of PAL gene was greater in root tissue than in leaf tissue after all treatments. Kolahi and coworkers [74] reported a similar pattern of PAL gene expression in different tissues of sugarcane, with the lowest level recorded in leaf tissue compared to sheath and root tissues. This may be due to the lack of vascular bundles and secondary tissues in leaf, as the PAL gene is implicated in plant growth and development via the lignin synthesis pathway, related to changes in lignin content and composition, as well as cell-wall production $[75,76]$.

\subsubsection{POD Gene}

In the oxidation of phenolic compounds and protection against pathogens, $\mathrm{POD}$ is a key scavenger of $\mathrm{H}_{2} \mathrm{O}_{2}$ and works in tandem with PAL [77,78]. In this study, upregulation of defensive gene POD was found following all treatments compared to UBI3. The highest relative expression of POD gene was recorded after treatment with BABA, followed by KA9 + PDS1 + RS, which exhibited threefold increased expression of POD gene compared to UBI3. A similar result was reported by Malviya et al. [79], who showed that the activities of plant enzymes such as peroxidase and superoxide dismutase were significantly increased in plant roots after the inoculation of plant growth-promoting Burkholderia anthina MYSP113 in sugarcane crops. In this study, POD expression was higher in root tissue, which agrees with the studies of Bharti et al. [80], who reported that PGPR-treated wheat roots showed a 2-3-fold increase in the gene expression of antioxidants compared to control plants, with comparatively less POD gene expression observed in wheat leaf tissues. A similar observation was recorded by Prakash et al. [81], whereby P. fluorescens elicited defensive gene expression in tomato plant against Alternaria blight disease.

\subsubsection{SOD Gene}

Superoxide dismutase (SOD) activity in plants is due to the expression of the corresponding SOD gene. SODs are important antioxidant enzymes that safeguard organisms against reactive oxygen species (ROS) produced under stress conditions [82]. In this study, a higher relative expression of SOD gene was recorded after dual rhizobacterial treat- 
ment compared to individual rhizobacterial treatments. The SOD gene was upregulated following all treatments compared to UBI3. Feng et al. [83] reported that Sl-SOD1 gene sustained high expression in all tested tomato tissues during growth and development. They also recorded a higher expression in root tissue, in line with the results of this study. Corpas et al. [84] used qRT-PCR to examine the expression of SOD isozymes in various olive leaf cell types, including spongy mesophyll, palisade mesophyll, xylem, and phloem. The highest concentration of superoxide radicals was seen in vascular tissue, which had the lowest number of SOD transcripts. These findings revealed that, depending on the cell type of the olive leaf, each SOD isozyme had a varied gene expression, which could explain the lower SOD expression in leaf tissue seen in this study. Zhou et al. [82] also reported a similar pattern of SOD gene expression in different cucumber tissues under various biotic and abiotic stresses.

\subsubsection{WRKYa and WRKY40 Genes}

WRKY is a conserved protein family implicated in a variety of biological processes in plants [85-87]. However, the mechanism underlying the functional diversity of WRKYs in chili has not been well elucidated. In this study, the relative expression of WRKYa gene exhibited a similar trend to that of other defensive genes, whereby dual rhizobacterial inoculation with B. subtilis KA9 and P. fluorescens PDS1 was found to be significantly better than other individual rhizobacterial treatments. Upregulation of defensive gene WRKYa was found after all treatments compared to UBI3 in root and leaf tissue. Upregulation of defensive gene WRKY40 was observed following BABA, PDS1 + KA9 + RS, and PDS1 + RS treatments, whereas downregulation was observed following KA9 + RS and RS treatments. This may be because WRKY transcription factors are interconnected with plant hormones and stress response pathways [88]. Nan and Gao [89] also analyzed gene expression using qRT-PCR and revealed that WRKY genes are involved in hormone and mechanic injury stresses. Nan et al. [90] characterized 39 orthologous gene pairs in rice WRKY (OsjWRKY) and performed qRT-PCR experiments to validate the tissue-specific and differential expression of OrWRKYs in response to abiotic stresses in leaves and roots; they found variable expression, in line with our results. Nan et al. [90] also studied the expression of 21 CaWRKY genes related to seven abiotic and biotic stimuli (heat shock, salt, drought, SA, Phytophthora capsici, ABA, and MeJA). Stress treatment increased the expression of several CaWRKY genes. According to Liu et al. [91], the WRKY40 transcription factor is known to positively influence the pepper plant's defense response to $R$. solanacearum. For transcriptional control and production of the defense gene, WRKY40 binds directly to the W4-box element of the ChiIV3 promoter region. ChiIV3 is influenced by WRKY40 gene regulation in a variety of ways. This may be the reason for the lower disease incidence in our treatments where WRKY gene expression was high.

\subsubsection{Relative Expression of CAT2 Gene}

Catalase is essential for the removal of $\mathrm{H}_{2} \mathrm{O}_{2}$ produced in the peroxisomes by photorespiration [92]. As a result of environmental stress, plant cells produce reactive oxygen species (ROS), which are free radicals that can damage membranes, oxidize proteins, and cause DNA damage $[93,94]$. Plants can be protected from biotic and abiotic stress conditions by altering the expression of ROS-scavenging enzymes such as peroxidase (POD), superoxide dismutase (SOD), and catalase (CAT) [95,96]. In this study, the highest relative expression of CAT2 gene was found in chili plants treated with BABA (3.75-fold). The relative expression observed after dual rhizobacterial treatment (KA9 + PDS1 + RS) was significantly better compared to individual rhizobacterial treatments. BABA was significantly different from rhizobacterial treatments. A different expression pattern in leaf and root tissue was recorded. A similar observation was also reported by Du et al. [97]. Greater expression of the CAT2 gene was detected in roots in this study, likely related to the sensitivity of catalase gene expression to the growth stage, light environment, and senescence [98], whereby 
different expression patterns may result from minor differences in developmental stages and growing circumstances.

Many studies have shown that stress activates catalase expression and activity in plants [99-105]. CAT1 exhibits very low levels of transcription and enzyme activity in normal conditions, but CAT2 may act as the main scavenger of $\mathrm{H}_{2} \mathrm{O}_{2}$ in response to stress, thereby playing an important role in adapting to environmental stresses. A greater incidence of wilting disease was recorded in chili plants with low CAT expression. A previous report indicated that deficiency of CAT2 reduced resistance in Arabidopsis plants [106].

\subsubsection{HFSC1 Gene}

Chili is mainly grown by farmers in kharif season in India, with the summer temperature commonly exceeding $35^{\circ} \mathrm{C}$. Therefore, to determine the effect of heat stress on chili growth and development, we evaluated HFSC gene expression. The relative expression of HFSC1 gene was lower in roots than in leaf tissue. This may be because of the direct exposure of leaves to heat in glasshouse conditions [107-109]. The highest relative expression of HFSC1 in leaves was recorded after treatment with KA9 + PDS1 + RS compared to the UBI3. Increased expression was observed after KA9 + PDS1 + RS treatment compared to individual rhizobacterial treatments. Thus, dual inoculation with B. subtilis KA9 and P. fluorescens PDS1 may reduce the heat stress of chili plants and improve their growth, as indicated by the highest plant growth parameter. Ali et al. [110] corroborate this claim, demonstrating that PGPR inoculation reduced the negative effects of heat stress on plant growth and output. Mukhtar et al. [111] conducted a study to investigate the potential of heat-tolerant PGPR in mitigating heat stress effects in tomatoes, and they discovered that B. cereus was particularly successful in alleviating heat stress. For example, when subjected to diverse abiotic stimuli such as heat, salt, and heavy metals, Tang et al. [61] found that the expression patterns of 12 RsHSF genes changed significantly. In our results, we also noted different expression patterns of the HSFC gene, which could be due to temperature differences in the glasshouse during the summer.

\subsubsection{LOX2 Gene}

Lipoxygenase (LOX) genes are abundant in plants and play an important role in biotic and abiotic stress resistance [112,113]. The LOX pathway's products serve as growth regulators, antibacterial chemicals, flavors and odors, and signaling molecules, among other functions [114]. In this study, dual culture treatment KA9 + PDS1 + RS showed the highest relative expression of LOX gene in root tissue. In leaves, the highest relative expression of LOX2 gene was recorded after RS treatment, while the lowest expression was recorded after BABA treatment, compared to UBI3. A similar result was reported by Song et al. [112], who reported that $L O X$ expression patterns differed significantly between wildtype peanut and cultivated peanut infected with Aspergillus flavus. Upregulation of defensive gene LOX2 in leaves was observed in all cases except after BABA treatment, compared to UBI3. A similar finding was also observed by Mariutto et al. [115] with CaLOX6 gene clusters, as SILOXF is known to be involved in systemic resistance to P. putida BTP1. Downregulation of the LOX gene was recorded by Zhang et al. [116] in vegetative tissues and fruit, in line with this study. AdLox 1 and AdLox 5 expression increased dramatically as the fruit reached the climacteric stage and was upregulated by ethylene treatment, following a pattern similar to the LOX enzyme activity seen here. However, ethylene buildup was inversely correlated with the AdLox2, AdLox3, and AdLox4 transcript levels. This could explain why BABA treatment led to a downregulation of LOX gene, due to a fluctuation in the hormones required for BABA to confer resistance [117].

\subsubsection{Relative Expression of NPR1 Gene}

NPR1 (nonexpresser of PR genes) is a master regulator of salicylic acid (SA) signaling, which is important for plant immunity. NPR1 interacts with transcription factors in the nucleus to boost defense responses by inducing the expression of PR (pathogenesis- 
related) genes [66]. In this study, the relative expression of NPR1 gene was highest after BABA treatment (3.13-fold). The downregulation of NPR1 gene in most cases indicates activation of a salicylic-acid-independent pathway, as less disease incidence was recorded, suggesting the induction of systemic resistance. As a master regulator of SAmediated and JA-mediated plant immunity [118], NPR1 controls the expression of over 2000 genes [119,120]. Ramirez et al. [121] investigated the role of the Arabidopsis mutant OCP3 in SA- and JA-dependent induced defense and discovered that OCP3 plants were impaired by $P$. fluorescens WCS417-triggered induced systemic resistance (ISR) against both P. syrinagae DC3000 and Hyaloperonospora arabidopsidis. Thus, rhizobacteria may affect NPR1's nucleocytosolic activity in the regulation of JA-dependent defensive responses. NPR1 facilitates the immunological transcriptome not only by activating SA-responsive genes but also by functioning as a corepressor of JA-responsive MYC2 [122].

\section{Conclusions}

Microbes can benefit agricultural systems by promoting plant growth and systemic resistance to diseases in plants without harming the environment. The plant growthpromoting efficiency of VOCs produced by Pseudomonas fluorescens PDS1 and Bacillus subtilis KA9 on chili against Ralstonia solanacearum was evaluated in a transparent closed assembly featuring a half-inverted plastic bottle setup, demonstrating the plant-microbial interactions via volatile compounds. The PDS1 and KA9 VOCs significantly increased defensive enzyme activity and overexpressed the antioxidant genes. The overall gene expression was higher in root tissue than in leaf tissue. Our findings shed light on the relationship among rhizobacteria, pathogens, and host plants, which promotes plant growth promotion, suppresses disease, induces systemic resistance, and triggers an antioxidant response in the leaves and roots of chili.

Supplementary Materials: The following are available online at https:/ /www.mdpi.com/article/ 10.3390/antiox11020404/s1, Supplementary Figure S1; Supplementary Figure S2; Supplementary Figure S3a-e; Supplementary Table S1; Supplementary Table S2; Supplementary Table S3; Supplementary Table S4; Supplementary Table S5; Supplementary Table S6; Supplementary Table S7; Supplementary Table S8; Supplementary Table S9; Supplementary Table S10; Supplementary Table S11; Supplementary Table S12; Supplementary M and M.

Author Contributions: Conceptualization and writing-original draft preparation, A.S.K.; writingreview and editing, A.S.K., N.M., and D.S.; writing-original draft preparation and investigation, A.S.K., N.M., and M.V.S.R.; funding acquisition, A.K.K., R.P.S., S.C.D., J.P.S., M.M.D., and S.M.N. All authors have read and agreed to the published version of the manuscript.

Funding: This research was funded by ICAR-IARI, New Delhi; IARI-Abhijeet_10333.

Institutional Review Board Statement: Not applicable.

Informed Consent Statement: Not applicable.

Data Availability Statement: Data is contained within the article or Supplementary Material.

Acknowledgments: The authors extend their gratitude to the Indian Council of Agricultural Research, New Delhi, the ICAR National Bureau of Agriculturally Important Microorganisms, Maunath Bhanjan, U.P India, and the University Grants Commission of India for providing financial assistance during the study. The authors wish to express their sincere thanks to Professor and Head, Division of Plant Pathology, IARI, New Delhi, India, for providing laboratory facilities, as well as A. Kumar, principal scientist, and Chandra Mani, T3, Division of Plant Pathology, IARI, for their valuable suggestions throughout the study.

Conflicts of Interest: The authors declare no conflict of interest. 


\section{References}

1. Hayward, A.C. Biology and epidemiology of bacterial wilt caused by Pseudomonas solanacearum. Annu. Rev. Phytopathol. 1991, 29, 65-87. [CrossRef]

2. Peeters, N.; Guidot, A.; Vailleau, F.; Valls, M. Ralstonia solanacearum, a widespread bacterial plant pathogen in the post-genomic era. Mol. Plant Pathol. 2013, 14, 651-662. [CrossRef]

3. Xue, Q.Y.; Chen, Y.; Li, S.M.; Chen, L.F.; Ding, G.C.; Guo, D.W. Evaluation of the strains of Acinetobacter and Enterobacter as potential biocontrol agents against Ralstonia wilt of tomato. Biol. Control 2009, 48, 252-258. [CrossRef]

4. Yunus, F.N.; Iqbal, M.; Jabeen, K.; Kanwal, Z.; Rashid, F. Antagonistic activity of Pseudomonas fluorescens against fungal plant pathogen Aspergillus niger. Sci. Lett. 2016, 4, 66-70.

5. Xie, S.; Wu, H.; Zang, H.; Wu, L.; Zhu, Q.; Gao, X. Plant growth promotion by Spermidine-producing Bacillus subtilis OKB105 MPMI 2014, 27, 655-663. [CrossRef] [PubMed]

6. Punja, Z.K.; Utkhede, R.S. Using fungi and yeasts to manage vegetable crop diseases. Trends Biotechnol. 2003, 21, 400-407. [CrossRef]

7. Idriss, E.E.; Makarewicz, O.; Farouk, A.; Rosner, K.; Greiner, R.; Bochow, H. Extracellular phytase activity of Bacillus amyloliquefaciens FZB45 contributes to its plant-growth-promoting effect. Microbiology 2002, 148, 2097-2109. [CrossRef]

8. Raza, W.; Ling, N.; Liu, D.; Wei, Z.; Huang, Q.; Shen, Q. Volatile organic compounds produced by Pseudomonas Fluorescens WR-1 restricts the growth and virulence traits of Ralstonia solanacearum. Microbiol. Res. 2016, 192, 103-113. [CrossRef]

9. Raza, W.; Ling, N.; Yang, L.; Huang, Q.; Shen, Q. Response of tomato wilt pathogen Ralstonia solanacearum to the volatile organic compounds produced by a biocontrol strain Bacillus amyloliquefaciens SQR-9. Sci. Rep. 2016, 6, 24856. [CrossRef]

10. Tahir, H.A.S.; Gu, Q.; Wu, H.; Niu, Y.; Huo, R.; Gao, X. Bacillus volatiles adversely affect the physiology and ultra-structure of Ralstonia solanacearum and induce systemic resistance in tobacco against bacterial wilt. Sci. Rep. 2017, 7, 40481. [CrossRef] [PubMed]

11. Tahir, H.A.S.; Gu, Q.; Wu, H.; Raza, W.; Hanif, A.; Wu, L. Plant growth promotion by volatile organic compounds produced by Bacillus subtilis SYST2. Front. Mol. Biol. 2017, 8, 1-11. [CrossRef]

12. Raza, W.; Yousaf, S.; Rajer, F.U. Plant growth promoting activity of volatile organic compounds produced by biocontrol strains Sci. Lett. 2016, 4, 40-43.

13. Ryu, C.; Farag, M.A.; Hu, C.; Reddy, M.S.; Wei, H.; Pare, P.W.; Kloepper, J.W. Bacterial volatiles promote growth in Arabidopsis Proc. Natl. Acad. Sci. USA 2003, 100, 4927-4932. [CrossRef] [PubMed]

14. Zou, C.; Li, Z.; Yu, D. Bacillus megaterium strain XTBG34 promotes plant growth by producing 2-pentylfuran. J. Microbiol. 2010, 48, 460-466. [CrossRef] [PubMed]

15. Lee, B.; Farag, M.A.; Park, H.B.; Kloepper, J.W.; Lee, S.H.; Ryu, C.M. Induced resistance by a long-chain bacterial volatile: Elicitation of plant systemic defense by a C13 volatile produced by Paenibacillus polymyxa. PLoS ONE 2012, 7, e48744. [CrossRef] [PubMed]

16. Park, Y.S.; Dutta, S.; Ann, M.; Raaijmakers, J.M.; Park, K. Promotion of plant growth by Pseudomonas Fluorescens strain SS101 via novel volatile organic compounds. Biochem. Biophys. Res. Commun. 2015, 461, 361-365. [CrossRef]

17. Rajer, F.U.; Wu, H.; Xie, Y.; Xie, S.; Raza, W.; Tahir, H.A.S. Volatile organic compounds produced by a soil-isolate, Bacillus subtilis FA26 induce adverse ultra-structural changes to the cells of Clavibacter michiganensis sp. sepedonicus, the causal agent of bacterial ring rot of potato. Microbiology 2017, 163, 523-530. [CrossRef]

18. Bailly, A.; Weisskopf, L. Current knowledge and future challenges. Plant Signal. Behav. 2012, 7, 1-7. [CrossRef]

19. Kai, M.; Piechulla, B. Impact of volatiles of the rhizobacteria Serratia odorifera on the moss Physcomitrella patens. Plant Signal. Behav. 2014, 5, 444-446. [CrossRef]

20. Ryu, C.; Farag, M.A.; Hu, C.; Reddy, M.S.; Kloepper, J.W.; Pare, P.W. Bacterial volatiles induce systemic resistance in Arabidopsis Plant Physiol. 2004, 134, 1017-1026. [CrossRef]

21. Song, G.C.; Ryu, C.M. Two volatile organic compounds trigger plant self-defense against a bacterial pathogen and a sucking insect in cucumber under open field conditions. Int. J. Mol. Sci. 2013, 14, 9803-9819. [CrossRef] [PubMed]

22. Zhang, H.; Kim, M.-S.; Krishnamachari, V.; Payton, P.; Sun, Y.; Grimson, M.; Frag, M.A.; Ryu, C.-M.; Allen, R.; Melo, I.S.; et al. Rhizobacterial volatile emissions regulate auxin homeostasis and cell expansion in Arabidopsis. Planta 2007, 226, 839-851. [CrossRef] [PubMed]

23. Ortíz-Castro, R.; Contreras-Cornejo, H.A.; Macías-Rodríguez, L.; López-Bucio, J. The role of microbial signals in plant growth and development. Plant Signal. Behav. 2014, 4, 701-712. [CrossRef] [PubMed]

24. Liu, A.; Zhang, P.; Bai, B.; Bai, F.; Jin, T.; Ren, J. Volatile organic compounds of endophytic Burkholderia pyrrocinia strain JK-SH007 promote disease resistance in poplar. Plant Dis. 2020, 104, 1610-1620. [CrossRef]

25. Francis, I.; Holsters, M.; Vereecke, D. The gram-positive side of plant-microbe interactions. Environ. Microbiol. 2010, 12, 1-12. [CrossRef]

26. Schaad, N.W.; Jone, J.B.; Lacy, G.H. Xanthomonas. In Laboratory Guide for Identification of Plant Pathogenic Bacteria, 3rd ed.; Schaad, N.W., Jones, J.B., Chun, W., Eds.; APS Press: St. Paul, MN, USA, 2001; pp. 175-200.

27. Guo, J. Nutrient-specific effects in the coordination of cell growth with cell division in continuous cultures of Saccharomyces cerevisiae. Arch. Microbiol. 2004, 182, 326-330. [CrossRef] 
28. Singh, D.; Yadav, D.K.; Chaudhary, G.; Rana, V.S.; Sharma, R.K. Potential of Bacillus amyloliquefaciens for Bio control of Bacterial Wilt of Tomato Incited by Ralstonia solanacearum. J. Plant Pathol. Microbiol. 2016, 7, 327. [CrossRef]

29. Kar, M.; Mishra, D. Catalase, peroxidase, and polyphenoloxidase activities during rice leaf senescence. Plant Physiol. 1976, 57, 315-319. [CrossRef]

30. Beauchamp, C.; Fridovich, I. Superoxide dismutase: Improved assays and an assay applicable to acrylamide gels. Anal. Biochem. 1971, 44, 276-287. [CrossRef]

31. Sadasivam, S.; Manickam, A. Biochemical Methods for Agricultural Sciences; Wiely Eastern Limited: New Delhi, India, 1992.

32. Sokal, R.R.; Rohlf, F.J. Biometry: The Principles and Practice of Statistics in Biological Research, 3rd ed.; W.H. Freeman and Co.: New York, NY, USA, 1995.

33. Kashyap, A.S.; Manzar, N.; Rajawat, M.V.S.; Kesharwani, A.K.; Singh, R.P.; Dubey, S.C.; Pattanayak, D.; Dhar, S.; Lal, S.K.; Singh, D. Screening and biocontrol potential of rhizobacteria native to gangetic plains and hilly regions to induce systemic resistance and promote plant growth in chilli against bacterial wilt disease. Plants 2021, 10, 2125. [CrossRef]

34. Spraker, J.E.; Jewell, K.; Roze, L.V.; Scherf, J.; Ndagano, D.; Beaudry, R.; Linz, J.E.; Allen, C.; Keller, N.P. A volatile relationship: Profiling an inter-kingdom dialogue between two plant pathogens. Ralstonia solanacearum and Aspergillus flavus. J. Chem. Ecol. 2014, 40, 502-513. [CrossRef] [PubMed]

35. Hernández-León, R.; Rojas-Solís, D.; Contreras-Pérez, M.; Orozco-Mosqueda, M.d.C.; Macías-Rodríguez, L.L.; Reyes-de la Cruz, H.; Valencia-Cantero, E.; Santoyo, G. Characterization of the antifungal and plant growth promoting effects of diffusible and volatile organic compounds produced by Pseudomonas fluorescens strains. Biol. Control 2015, 81, 83-92. [CrossRef]

36. Dandurishvili, N.; Toklikishvili, N.; Ovadis, M.; Eliashvili, P.; Giorgobiani, N.; Keshelava, R. Broad-range antagonistic rhizobacteria, Pseudomonas fluorescens and Serratia plymuthica suppress Agrobacterium crown gall tumours on tomato plants. J. Appl. Microbiol. 2011, 110, 341-352. [CrossRef] [PubMed]

37. Gao, Z.; Zhang, B.; Liu, H.; Han, J.; Zhang, Y. Identification of endophytic Bacillus velezensis ZSY-1 strain and antifungal activity of its volatile compounds against Alternaria solani and Botrytis cinerea. Biol. Control 2017, 105, 27-39. [CrossRef]

38. Figueredo, M.S.; Tonelli, M.L.; Ibáñez, F.; Morla, F.; Cerioni, G.; Tordable, M.; Fabra, A. Induced systemic resistance and symbiotic performance of peanut plants challenged with fungal pathogens and co-inoculated with the biocontrol agent Bacillus sp. CHEP5 and Bradyrhizobium sp. SEMIA6144. Microbiol. Res. 2017, 197, 65-73. [CrossRef]

39. Jayapala, N.; Mallikarjunaiah, N.; Puttaswamy, H. Rhizobacteria Bacillus spp. induce resistance against anthracnose disease in chili (Capsicum annuum L.) through activating host defense response. Egypt. J. Biol. Pest Control 2019, 29, 45. [CrossRef]

40. Thilagavathi, R.; Saravanakumar, D.; Ragupathi, N.; Samiyappan, R. A combination of biocontrol agents improves the management of dry root rot (Macrophomina phaseolina) in greengram. Phytopathol. Mediterr. 2007, 46, 157-167.

41. Li, C.; Hu, W.; Pan, B.; Liu, Y.; Yuan, S.; Ding, Y.; Li, R.; Zheng, X.; Shen, B.; Shen, Q. rhizobacterium Bacillus amyloliquefaciens strain SQRT3-mediated induced systemic resistance controls bacterial wilt of tomato. Pedosphere 2017, 27, 1135-1146. [CrossRef]

42. Ramamoorthy, V.; Viswanathan, R.; Raguchander, T.; Prakasam, V.; Samiyappan, R. Induction of systemic resistance by plant growth promoting rhizobacteria in crop plants against pests and diseases. Crop Prot. 2001, 20, 1-11. [CrossRef]

43. Ho, F.I.; Chen, Y.Y.; Lin, Y.M.; Cheng, C.P.; Wang, J.F. A tobacco rattle virus-induced gene silencing system for a soil-borne vascular pathogen Ralstonia solanacearum. Bot. Stud. 2009, 50, 413-424.

44. Chandrasekaran, M.; Chun, S.C. Expression of PR-protein genes and induction of defense-related enzymes by Bacillus subtilis CBR05 in tomato (Solanum lycopersicum) plants challenged with Erwinia carotovora subsp carotovora. Biosci. Biotechnol. Biochem. 2016, 80, 2277-2283. [CrossRef]

45. Li, W.; Mo, W.; Ashraf, U.; Li, G.; Wen, T.; Abrar, M.; Gao, L.; Liu, J.; Hu, J. Evaluation of physiological indices of waterlogging tolerance of different maize varieties in South China. Appl. Ecol. Environ. Res. 2018, 16, 2059-2072. [CrossRef]

46. Hasanuzzaman, M.; Bhuyan, M.H.M.B.; Zulfiqar, F.; Raza, A.; Mohsin, S.M.; Mahmud, J.A.; Fujita, M.; Fotopoulos, V. Reactive oxygen species and antioxidant defense in plants under abiotic stress: Revisiting the crucial role of a universal defense regulator. Antioxidants 2020, 29, 681. [CrossRef] [PubMed]

47. Vanitha, S.C.; Niranjana, S.R.; Mortensen, C.N.; Umesha, S. Bacterial wilt of tomato in Karnataka and its management by Pseudomonas fluorescens. Biocontrol 2009, 54, 685-695. [CrossRef]

48. Xu, L.; Zhu, L.; Tu, L.; Liu, L.; Yuan, D.; Jin, L.; Long, L.; Zhang, X. Lignin metabolism has a central role in the resistance of cotton to the wilt fungus Verticillium dahliae as revealed by RNA-Seq-dependent transcriptional analysis and histochemistry. J. Exp. Bot. 2011, 62, 5607-5621. [CrossRef]

49. Gayoso, C.; Pomar, F.; Novo Uzal, E.; Merino, F.; de Ilárduya, Ó.M. The Ve-mediated resistance response of the tomato to Verticillium dahliae involves $\mathrm{H}_{2} \mathrm{O}_{2}$, peroxidase and lignins and drives PAL gene expression. BMC Plant Biol. 2010, 10, 232-250. [CrossRef]

50. Mittler, R.; Vanderauwera, S.; Gollery, S.; Breusegem, V. Reactive oxygen gene network of plants. Trends Plant Sci. 2004, 9, 490-498. [CrossRef]

51. Akram, W.; Anjum, T. Use of bioagents and synthetic chemicals for induction of systemic resistance in tomato against diseases. Int. R. J. Agric. Sci. Soil Sci. 2011, 1, 286-292.

52. Wang, F.; Cui, X.; Sun, Y.; Dong, C.H. Ethylene signaling and regulation in plant growth and stress responses. Plant Cell Rep. 2013, 32, 1099-1109. [CrossRef] 
53. Zhang, Y.; Li, J.; Zhang, W.; Shi, H.; Luo, F.; Hikichi, Y.; Shi, X.; Ohnishi, K. A putative LysR-type transcriptional regulator PrhO positively regulates the type III secretion system and contributes to the virulence of Ralstonia solanacearum. Mol. Plant Pathol. 2018, 19, 1808-1819. [CrossRef]

54. Li, X.; Zhang, H.; Ai, Q.; Liang, G.; Yu, D. Two bHLH transcription factors, bHLH34 and bHLH104, regulate iron homeostasis in Arabidopsis thaliana. Plant Physiol. 2016, 170, 2478-2493. [CrossRef] [PubMed]

55. Wang, K.; Liu, H.; Du, L.; Ye, X. Generation of marker-free transgenic hexaploid wheat via an Agrobacterium-mediated cotransformation strategy in commercial Chinese wheat varieties. Plant Biotechnol. J. 2017, 15, 614-623. [CrossRef] [PubMed]

56. Kong, L.; Cheng, J.; Zhu, Y.; Ding, Y.; Meng, J.; Chen, Z.; Xie, Q.; Guo, Y.; Li, J.; Yang, S.; et al. Degradation of the ABA co-receptor ABI1 by PUB12/13 U-box E3 ligases. Nat. Commun. 2015, 6, 8630. [CrossRef] [PubMed]

57. Noonam, J.; Williams, W.P.; Shan, X. Investigation of antimicrobial peptide genes associated with fungus and insect resistance in maize. Int. J. Mol. Sci. 2018, 18, 1938. [CrossRef]

58. Luo, Y.-X.; Hou, X.-M.; Zhang, C.-J.; Tan, L.-M.; Shao, C.-R.; Lin, R.-N.; Su, Y.-N.; Cai, X.-W.; Li, L.; Chen, S.; et al. A plant-specific SWR1 chromatin-remodeling complex couples' histone H2A.Z deposition with nucleosome sliding. EMBO J. 2020, 39 , e102008. [CrossRef]

59. Cheng, Y.; Jalal, A.G.; Yu, J.; Yao, Z.; Ruan, M.; Ye, Q.; Li, Z.; Wang, R.; Feng, K.; Zhou, G.; et al. Putative WRKYs associated with regulation of fruit ripening revealed by detailed expression analysis of the WRKY gene family in pepper. Sci. Rep. 2016, 6, 39000. [CrossRef]

60. Singh, D.; Shweta, S.; Garima, C.; Yadav, D.K. Biological characterization and genetic diversity of Indian strains of Ralstonia solanacearum biovars 3 and 4 causing bacterial wilt of tomato. J. Plant Pathol. Microbiol. 2018, 9, 2. [CrossRef]

61. Tang, M.; Xu, L.; Wang, Y.; Cheng, W.; Luo, X.; Xie, Y.; Fan, L.; Liu, L. Genome-wide characterization and evolutionary analysis of heat shock transcription factors (HSFs) to reveal their potential role under abiotic stresses in radish (Raphanus sativus L.). BMC Genom. 2019, 20, 772. [CrossRef]

62. Liu, C.; Xin, Y.; Xu, L.; Cai, Z.; Xue, Y.; Liu, Y.; Xie, D.; Liu, Y.; Qi, Y. Arabidopsis ARGONAUTE 1 binds chromatin to promote gene transcription in response to hormones and stresses. Dev. Cell 2018, 44, 348-361.e7. [CrossRef]

63. Tolosa, L.N.; Zhang, Z. The role of major transcription factors in solanaceous food crops under different stress conditions: Current and future perspectives. Plants 2020, 9, 56. [CrossRef]

64. Lin, W.C.; Lu, C.F.; Wu, J.W.; Cheng, M.-L.; Lin, Y.-M.; Yang, N.-S.; Black, L.; Green, S.K.; Wang, J.-W.; Cheng, C.-P. Transgenic tomato plants expressing the Arabidops is NPR1 gene display enhanced resistance to a spectrum of fungal and bacterial diseases. Transgenic Res. 2004, 13, 567-581. [CrossRef] [PubMed]

65. Shu, L.J.; Liao, J.Y.; Lin, N.C.; Chung, C.L. Identification of a strawberry NPR-like gene involved in negative regulation of the salicylic acid-mediated defense pathway. PLoS ONE 2018, 13, e0205790. [CrossRef] [PubMed]

66. Chen, J.; Mohan, R.; Zhang, Y.; Li, M.; Chen, H.; Palmer, I.A.; Chang, M.; Qi, G.; Spoel, S.H.; Mengiste, T. NPR1 promotes its own and target gene expression in plant defense by recruiting CDK8. Plant Physiol. 2019, 181, 289-304. [CrossRef] [PubMed]

67. Cass, C.L.; Peraldi, A.; Dowd, P.F.; Mottiar, Y.; Santoro, N.; Karlen, S.D.; Bukhman, Y.V.; Foster, C.E.; Thrower, N.; Bruno, L.C Effects of Phenylalanine Ammonia Lyase (PAL) knockdown on cell wall composition, biomass digestibility, and biotic and abiotic stress responses in Brachypodium. J. Exp. Bot. 2015, 66, 4317-4335. [CrossRef]

68. Gupta, R.; Singh, A.; Srivastava, M.; Singh, V.; Gupta, M.M.; Pandey, R. Microbial modulation of bacoside; A biosynthetic pathway and systemic defense mechanism in Bacopa monnieri under Meloidogyne incognita stress. Sci. Rep. 2017, 7, 41867-41877. [CrossRef]

69. Kim, D.S.; Hwang, B.K. An important role of the pepper phenylalanine ammonia-lyase gene (PAL1) in salicylic acid-dependent signalling of the defense response to microbial pathogens. J. Exp. Bot. 2014, 65, 2295-2306. [CrossRef]

70. Chen, Y.; Li, F.; Tian, L.; Huang, M.; Deng, R.; Li, X. The phenylalanine ammonia lyase gene LjPAL1 is involved in plant defense responses to pathogens and plays diverse roles in Lotus japonicus-rhizobium symbioses. Mol. Plant-Microbe Interact. MPMI 2017, 30, 739-753. [CrossRef]

71. Zhang, C.; Wang, X.; Zhang, F.; Dong, L.; Wu, J.; Cheng, Q. Phenylalanine ammonia-lyase2.1 contributes to the soybean response towards Phytophthora sojae infection. Sci. Rep. 2017, 7, 7242-7255. [CrossRef]

72. Zhang, H.; Huang, Q.; Yi, L.; Song, X.; Li, L.; Deng, G.; Liang, J.; Chen, F.; Yu, M.; Long, H. PAL-mediated SA biosynthesis pathway contributes to nematode resistance in wheat. Plant J. 2021, 107, 698-712. [CrossRef]

73. Wang, X.; Wang, L.; Wang, J.; Jin, P.; Liu, H.; Zheng, Y. Bacillus cereus AR156-induced resistance to Colletotrichum acutatum is associated with priming of defense responses in loquat fruit. PLoS ONE 2014, 9, 11. [CrossRef]

74. Kolahi, M.; Jonoubi, P.; Majd, A.; Tabandeh, M.R.; Hashemitabar, M. Expression of phenylalanine. Bioresources 2013, 8, 4912-4922.

75. Wang, J.P.; Matthews, M.L.; Williams, C.M.; Shi, R.; Yang, C.; Tunlaya-Anukit, S.; Chen, H.-C.; Li, Q.; Liu, J.; Lin, C.Y.; et al. Improving wood properties for wood utilization through multi-omics integration in 13 lignin biosynthesis. Nat. Commun. 2018, 9, 1579. [CrossRef] [PubMed]

76. Yadav, V.; Wang, Z.; Wei, C.; Amo, A.; Ahmed, B.; Yang, X.; Zhang, Z. Phenylpropanoid Pathway Engineering: An Emerging Approach towards Plant Defense. Pathogens 2020, 9, 312. [CrossRef] [PubMed]

77. Li, H.L.; Deng, H.P.; Sun, Z.Y.; Zhao, L.J.; Han, L.; Ju, G.S.; Qian, Y.Q. Effect of methyl jasmonate on physiological indexes of chrysanthemum cuttage under natural drought stress. For. Res. 2010, 23, 733-737.

78. Almagro, L.; Gómez Ros, L.V.; Belchi-Navarro, S.; Bru, R.; Ros Barceló, A.; Pedreno, M.A. Class III peroxidases in plant defense reactions. J. Exp. Bot. 2009, 60, 377-390. [CrossRef] [PubMed] 
79. Malviya, M.K.; Li, C.N.; Solanki, M.K.; Singh, R.K.; Htun, R.; Singh, P.; Verma, K.K.; Yang, L.-T.; Li, Y.-R. Comparative analysis of sugarcane root transcriptome in response to the plant growth-promoting Burkholderia anthina MYSP113. PLoS ONE 2020, 15, e0231206. [CrossRef]

80. Bharti, N.; Pandey, S.S.; Barnawal, D.; Patel, V.K.; Kalra, A. Plant growth promoting rhizobacteria Dietzia natronolimnaea modulates the expression of stress responsive genes providing protection of wheat from salinity stress. Sci. Rep. 2016, 6, 34768. [CrossRef]

81. Prakash, N.; Vishunavat, K.; Khan, G.T.; Prasad, P. SA, ABA and pseudomonas fluorescens elicit defense responses in tomato against Alternaria blight. J. Plant Biochem. Biotechnol. 2021, 30, 13-25. [CrossRef]

82. Zhou, Y.; Hu, L.H.; Wu, H.; Jiang, L.W.; Liu, S.Q. Genome-wide identification and transcriptional expression analysis of cucumber superoxide dismutase (SOD) family in response to various abiotic stresses. Int. J. Genom. 2017, 2017, 1-14. [CrossRef]

83. Feng, K.; Yu, J.; Cheng, Y.; Ruan, M.; Wang, R.; Zhou, G.; Li, Z.; Yao, Z.; Yang, Y.; Zheng, Q.; et al. The SOD gene family in tomato: Identification, phylogenetic relationships, and expression patterns. Front. Plant Sci. 2016, 7, 1279-1291. [CrossRef]

84. Corpas, F.J.; Fernández-Ocaña, A.; Carreras, A.; Valderrama, R.; Luque, F.; Esteban, F.J. The expression of different superoxide dismutase forms is cell-type dependent in olive (Olea europaea L) leaves. Plant Cell Physiol. 2006, 47, 984-994. [CrossRef]

85. Cai, Y.; Chen, X.; Xie, K.; Xing, Q.; Wu, Y.; Li, J.; Du, C.; Sun, Z.; Guo, Z. Dlf1, a WRKY transcription factor, is involved in the control of flowering time and plant height in rice. PLoS ONE 2014, 9, e102529. [CrossRef] [PubMed]

86. Zhou, M.; Lu, Y.; Bethke, G.; Harrison, B.T.; Hatsugai, N.; Katagiri, F.; Glazebrook, J. WRKY70 prevents axenic activation of plant immunity by direct repression of SARD1. New Phytol. 2018, 217, 700-712. [CrossRef] [PubMed]

87. Cheng, X.; Zhao, Y.; Jiang, Q.; Yang, J.; Zhao, W.; Taylor, I.A.; Peng, Y.-L.; Wang, D.; Liu, J. Structural basis of dimerization and dual W-box DNA recognition by rice WRKY domain. Nucleic Acids Res. 2019, 47, 4308-4318. [CrossRef] [PubMed]

88. Cheng, H.; Liu, H.; Deng, Y.; Xiao, J.; Li, X.; Wang, S. The WRKY45-2 WRKY13 WRKY42 transcriptional regulatory cascade is required for rice resistance to fungal pathogen. Plant Physiol. 2015, 167, 1087-1099. [CrossRef]

89. Nan, H.; Gao, L.Z. Genome-wide analysis of WRKY genes and their response to hormone and mechanic stresses in carrot. Front. Genet. 2019, 10, 363. [CrossRef]

90. Nan, H.; Li, W.; Lin, Y.-1.; Gao, L.-z. Genome-wide analysis of WRKY genes and their response to salt stress in the wild progenitor of Asian cultivated rice, oryza rufipogon. Front. Genet. 2020, 11, 359. [CrossRef]

91. Liu, Z.; Shi, L.; Weng, Y.; Zou, H.; Li, X.; Yang, S.; Qiu, S.; Huang, X.; Huang, J.; Hussain, A.; et al. ChiIV3 Acts as a novel target of WRKY40 to mediate pepper immunity against Ralstonia solanacearum infection. Mol. Plant Microbe Interact. 2019, 32, 1121-1133. [CrossRef]

92. Noctor, G.; Veljovic-Jovanovic, S.D.; Driscoll, S.; Novitskaya, L.; Foyer, C.H. Drought and oxidative load in wheat leaves. A predominant role for photorespiration? Ann. Bot. 2002, 89, 841-850. [CrossRef]

93. Hasanuzzaman, M.; Bhuyan, M.; Anee, T.I.; Parvin, K.; Nahar, K.; Mahmud, J.A.; Fujita, M. Regulation of ascorbate-glutathione pathway in mitigating oxidative damage in plants under abiotic stress. Antioxidants 2019, 8, 384. [CrossRef]

94. Laxa, M.; Liebthal, M.; Telman, W.; Chibani, K.; Dietz, K.-J. The role of the plant antioxidant system in drought tolerance. Antioxidants 2019, 8, 94. [CrossRef] [PubMed]

95. Spinedi, N.; Storb, R.; Aranda, E.; Romani, F.; Svriz, M.; Varela, S.A.; Moreno, J.E.; Fracchia, S.; Cabrera, J.; Batista-García, R.A.; et al. ROS-Scavenging Enzymes as an Antioxidant Response to High Concentration of Anthracene in the Liverwort. Marchantia polymorpha L. Plants 2021, 10, 1478. [CrossRef] [PubMed]

96. Filiz, E.; Tombuloğlu, H. Genome-wide distribution of superoxide dismutase (SOD) gene families in Sorghum bicolor. Turk. J. Biol. 2014, 39, 49-59. [CrossRef]

97. Du, Y.-Y.; Wang, P.-C.; Chen, J.; Song, C.-P. Comprehensive functional analysis of the catalase gene family in Arabidopsis thaliana. J. Integr. Plant Biol. 2008, 50, 1318-1326. [CrossRef]

98. Zimmermann, P.; Heinlein, C.; Orendi, G.; Zentgraf, U. Senescence-specific regulation of catalases in Arabidopsis thaliana (L.) Heynh. Plant Cell Environ. 2006, 29, 1049-1060. [CrossRef]

99. Williamson, J.D.; Scandalios, J.G. Differential response of Maize catalases to abscisic acid: Vp1 transcriptional activator is not required for abscisic acid-regulated cat1 expression. Proc. Natl. Acad. Sci. USA 1992, 89, 8842-8846. [CrossRef]

100. Guan, L.M.; Scandalios, J.G. Catalase transcript accumulation in response to dehydration and osmotic stress in leaves of maize viviparous mutants. Redox Rep. 2000, 5, 377-383. [CrossRef]

101. Orendi, G.; Zimmermann, P.; Baar, C.; Zentgraf, U. Loss of stress-induced expression of catalase3 during leaf senescence in Arabidopsis thaliana is restricted to oxidative stress. Plant Sci. 2001, 161, 301-314. [CrossRef]

102. Vandenabeele, S.; Vanderauwera, S.; Vuylsteke, M.; Rombauts, S.; Langebartels, C.; Seidlitz, H.K. Catalase deficiency drastically affects gene expression induced by high light in Arabidopsis thaliana. Plant J. 2004, 39, 45-58. [CrossRef]

103. Luna, C.M.; Pastori, G.M.; Driscoll, S.; Groten, K.; Bernard, S.; Foyer, C.H. Drought controls on $\mathrm{H}_{2} \mathrm{O}_{2}$ accumulation, catalase (CAT) activity and CAT gene expression in wheat. J. Exp. Bot. 2005, 56, 417-442. [CrossRef]

104. Verslues, P.E.; Batelli, G.; Grillo, S.; Agius, F.; Kim, Y.S.; Zhu, J. Interaction of SOS2 with NDPK2 and catalases reveals a point of connection between salt stress and $\mathrm{H}_{2} \mathrm{O}_{2}$ signaling in Arabidopsis. Mol. Cell. Biol. 2007, 27, 7771-7780. [CrossRef] [PubMed]

105. Xing, Y.; Jia, W.; Zhang, J. AtMEK1 mediates stress-induced gene expression of CAT1 catalase by triggering $\mathrm{H}_{2} \mathrm{O}_{2}$ production in Arabidopsis. J. Exp. Bot. 2007, 58, 2969-2981. [CrossRef] [PubMed] 
106. Vanderauwera, S.; Zimmermann, P.; Rombauts, S.; Vandenabeele, S.; Langebartels, C.; Gruissem, W.; Inze, D.; van Breusegem, F. Genome-wide analysis of hydrogen peroxide-regulated gene expression in Arabidopsis reveals a high light-induced transcriptional cluster involved in anthocyanin biosynthesis. Plant Physiol. 2005, 139, 806-821. [CrossRef] [PubMed]

107. Scharf, K.D.; Berberich, T.; Ebersberger, I.; Nover, L. The plant heat stress transcription factor (Hsf) family: Structure, function and evolution. Biochim. Et Biophys. Acta (BBA)-Gene Regul. Mech. 2012, 1819, 104-119. [CrossRef]

108. Guo, M.; Liu, J.-H.; Ma, X.; Luo, D.-X.; Gong, Z.-H.; Lu, M.-H. The plant heat stress transcription factors (HSFs): Structure, regulation, and function in response to abiotic stresses. Front. Plant Sci. 2016, 7, 114. [CrossRef]

109. Huang, B.; Huang, Z.; Ma, R.; Chen, J.; Zhang, Z.; Yrjala, K. Genome-wide identification and analysis of the heat shock transcription factor family in moso bamboo (Phyllostachys edulis). Sci. Rep. 2021, 11, 16492. [CrossRef]

110. Ali, S.Z.; Sandhya, V.; Grover, M.; Linga, V.R.; Bandi, V. Effect of inoculation with a thermotolerant plant growth promoting Pseudomonas putida strain AKMP7 on growth of wheat (Triticum spp.) under heat stress. J. Plant Interact. 2011, 6, 239-246. [CrossRef]

111. Mukhtar, T.; Rehman, S.u.; Smith, D.; Sultan, T.; Seleiman, M.F.; Alsadon, A.A.; Amna; Ali, S.; Chaudhary, H.J.; Solieman, T.H.I.; et al. Mitigation of Heat Stress in Solanum lycopersicum L. by ACC-deaminase and Exopolysaccharide Producing Bacillus cereus: Effects on Biochemical Profiling. Sustainability 2020, 12, 2159. [CrossRef]

112. Song, H.; Wang, P.; Li, C.; Han, S.; Lopez-Baltazar, J.; Zhang, X.; Wang, X. Identification of lipoxygenase (LOX) genes from legumes and their responses in wild type and cultivated peanut upon Aspergillus flavus infection. Sci. Rep. 2016, 6, 35245. [CrossRef]

113. Sarde, S.J.; Kumar, A.; Remme, R.N.; Dicke, M. Genome-wide identification, classification and expression of lipoxygenase gene family in pepper. Plant Mol. Biol. 2018, 98, 375-387. [CrossRef]

114. Rosahl, S. Lipoxygenases in plants-Their role in development and stress response. Z. Naturforsch. 1996, 51, 123-138. [CrossRef] [PubMed]

115. Mariutto, M.; Duby, F.; Adam, A.; Bureau, C.; Fauconnier, M.L.; Ongena, M.; Thonart, P.; Dommes, J. The elicitation of a systemic resistance by Pseudomonas putida BTP1 in tomato involves the stimulation of two lipoxygenase isoforms. BMC Plant Biol. 2011, 11, 29. [CrossRef] [PubMed]

116. Zhang, B.; Chen, K.S.; Bowen, J.; Allan, A.; Espley, R.; Karunairetnam, S.; Ferguson, I. Differential expression within the LOX gene family in ripening kiwifruit. J. Exp. Bot. 2006, 57, 3825-3836. [CrossRef] [PubMed]

117. Cohen, Y.R. $\beta$-Aminobutyric acid-induced resistance against plant pathogens. Plant Dis. 2002, 86, 448-457. [CrossRef]

118. Koornneef, A.; Pieterse, C.M. Cross talk in defense signaling. Plant Physiol. 2008, 146, 839-844. [CrossRef]

119. Wang, D.; Amornsiripanitch, N.; Dong, X. A genomic approach to identify regulatory nodes in the transcriptional network of systemic acquired resistance in plants. PLoS Pathog. 2006, 2, 1371. [CrossRef]

120. Fu, Z.Q.; Dong, X. Systemic acquired resistance: Turning local infection into global defense. Annu. Rev. Plant Biol. 2013, 64, 839-863. [CrossRef]

121. Ramírez, D.P.; Ryan, B.; Grüning, V.; Bhardwaj, F.; Kilpert, A.S.; Richter, S.; Heyne, F.; Dündar, T. Manke deepTools2, a next generation web server for deep-sequencing data analysis. Nucleic Acids Res. 2016, 44, 160. [CrossRef]

122. Nomoto, M.; Skelly, M.J.; Itaya, T.; Mori, T.; Suzuki, T.; Matsushita, T.; Tokizawa, M.; Kuwata, K.; Mori, H.; Yoshiharu, Y.; et al. Suppression of MYC Transcription activators by the immune cofactor NPR1 fine-tunes plant immune responses. Cell Rep. 2021, 37, 110125. [CrossRef] 